\title{
Material Memory
}

by

Michelle McKenna

A thesis submitted to the Faculty of Graduate and Postdoctoral Affairs in partial fulfillment of the requirements for the degree of

Master of Architecture

Carleton University

Ottawa, Ontario

(C) 2016

Michelle McKenna 
Material Memory 


\begin{abstract}
Through the depression, the Second World War, and the postwar decades of expanding scientific research and economic growth, the Energy Mines and Resources Complex in Ottawa stood at the forefront of Canadian technological research and innovation. Shuttered since 2001, the complex - a collection of remarkable historic buildings made for research and development-now stands empty.

Material Memory explores narratives of Canada's modern industrial history. The project investigates the potential of rerepresentation, through the creation of a physical archive of the complex and the artefacts located therein, to deepen our understanding of place. Purposeful appropriation of, and additions to the historical EMRC buildings provide means for reimagining the futures of urban industrial complexes and governmental sites.
\end{abstract}




\section{Acknowledgments}

This thesis is dedicated to Diogo Seixas Lopes, whose teachings will continue to influence the way I make architecture.

Thank you first to my parents, who have provided me with unconditional support and encouragement, and to my advisor Inderbir, whose guidance throughout the research and design process has been invaluable.

Thank you to the faculty and staff at the school of architecture who make it possible for students to materialise ideas. 


\section{Table of Contents}

Abstract $\quad$ ii

Acknowledgments iii

Chapter 1: Introduction 1

The Energy, Mines and Resources Complex 1

Ottawa's Industrial History 2

A Part of Our Heritage 9

New Modes of Preservation 13

$\begin{array}{ll}\text { Science and Craft } & 14\end{array}$

$\begin{array}{ll}\text { Thesis Question } & 16\end{array}$

$\begin{array}{ll}\text { Chapter 2: Preservation } & 17\end{array}$

$\begin{array}{ll}\text { Preserving the Banal } & 17\end{array}$

$\begin{array}{ll}\text { Inherent Character } & 19\end{array}$

$\begin{array}{ll}\text { Against Erasure } & 20\end{array}$

Chapter 3: Representation $\quad 22$

The Problem with Representation $\quad 22$

$\begin{array}{ll}\text { Individuality } & 23\end{array}$

$\begin{array}{ll}\text { Dynamism } & 27\end{array}$

Chapter 4: Making Tools for Making Material History 29

Other Means of Preservation 29

Artist Case Studies 33

Human Traces 36

The Foundry $\quad 39$

Casting Rockite 41

Casting Plaster $\quad 43$ 
Chapter 5: Program

The Benefits of Manual Work

Generative Space

The Archive

Chapter 6: The Architecture

Site Strategy

Tectonics

Forensic Architecture

Authenticity

The Archive

Conclusion 


\title{
Chapter 1: Introduction
}

\begin{abstract}
"It is true that numerous commercial firms, as well as some public laboratories, have experimental plants for specific purposes that are not found in Ottawa; but a scrutiny of the general-purpose laboratories for metallurgical research, both in this continent and overseas, reveals the somewhat startling but wholly satisfactory situation... that we have in this country the best in existence today." 1

- Canadian Mining Journal, 1930
\end{abstract}

\section{The Energy, Mines and Resources Complex}

The Energy, Mines and Resources Complex (EMRC) in Ottawa represents a critical moment in the centralization of scientific and technical knowledge production in Canada. Together, the stock market crash of 1929, The Public Works Construction Act of 1934, and Canada's declaration of war in September 1939, set the stage for the rapid expansion of EMRC during the 1930s and 1940s. Industrial research became a crucial component of national identity and integral to the built fabric of the nation's capital. 


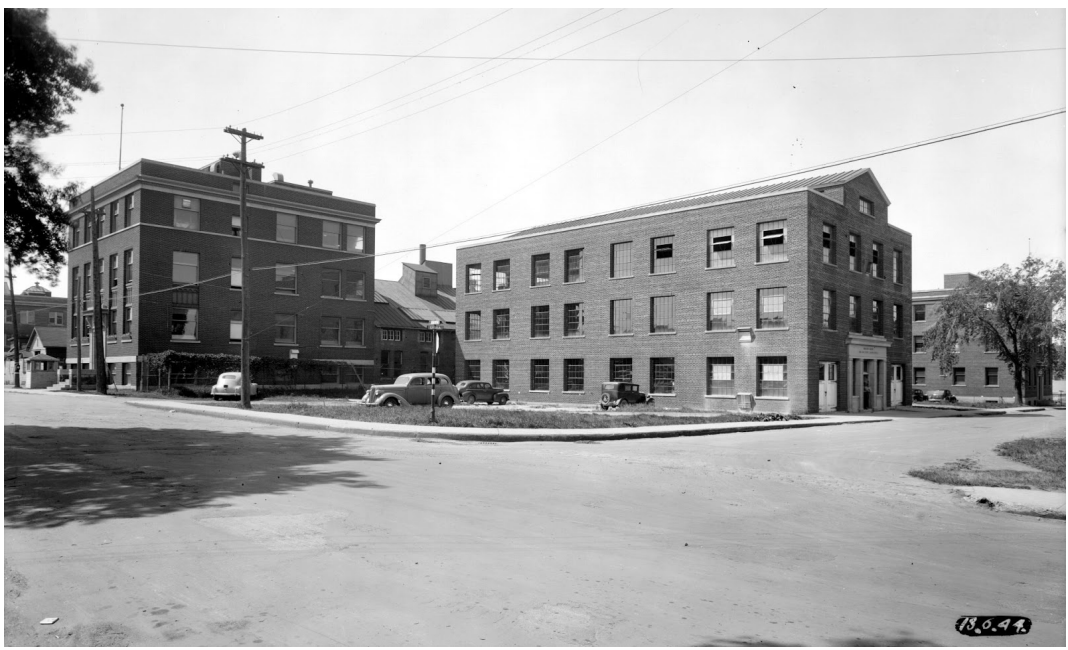

1. The Energy Mines and Resources Complex, 1938

(urbsite.blogspot.ca)

EMRC is a physical manifestation of cultural, political and economic events that shaped the nation's identity in the early $20^{\text {th }}$ century. While their future is unclear, it is likely that the buildings of EMRC will soon be demolished or, at the very least, scrubbed of any signs of age that contributes to their collective identity.

\section{Ottawa's Industrial History}

After growing as a bustling lumber town for several decades, Bytown was successfully incorporated as a city in 1850 . The city changed its name to Ottawa in 1855 , 
named after the river that provided its wealth. Ottawa was selected by Queen Victoria as Canada's national capital in $1857 .^{2}$ Over the next fifty years, the city's urban fabric was characterised by saw mills and processing plants. The lumber industry began to decline after the HullOttawa fire of 1900 which destroyed the Chaudière mills, clearing the way for the Federal Government to become the primary influence on the city's built environment and economy. ${ }^{3}$

The Federal Government purchased the first parcel of land for EMRC in 1908. The property was located in the Dalhousie Ward, then considered the edge of the city and adjacent to railway tracks and lumber yards (figures 2, $3)$. Over the next 30 years the complex developed as a world-class centre for scientific research. ${ }^{4}$

During the 1930s and 1940s, the Department of Mines experienced a period of rapid expansion as a result of governmental initiatives to counter the Great Depression as well as Canada's involvement in World War II. ${ }^{5}$ The Public Works Construction Act of 1934 was designed as 


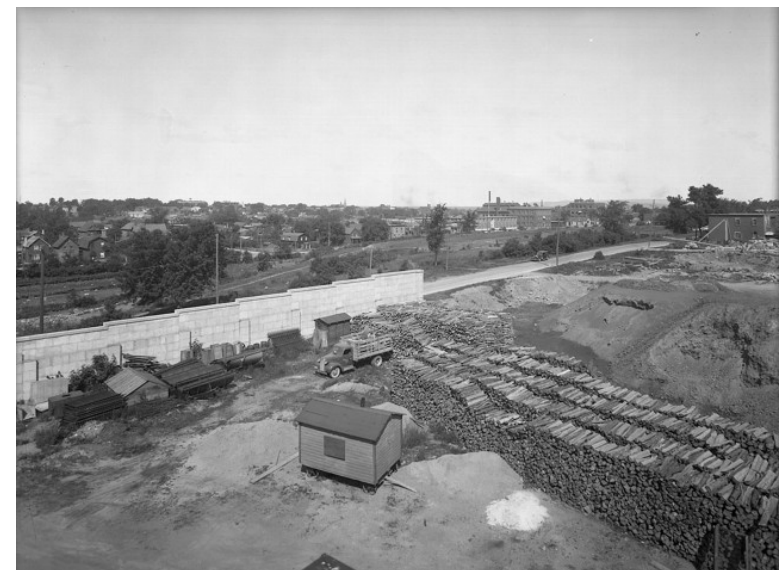

2. Booth St. Lumber Yard and EMRC, 1938 (pastottawa.com)

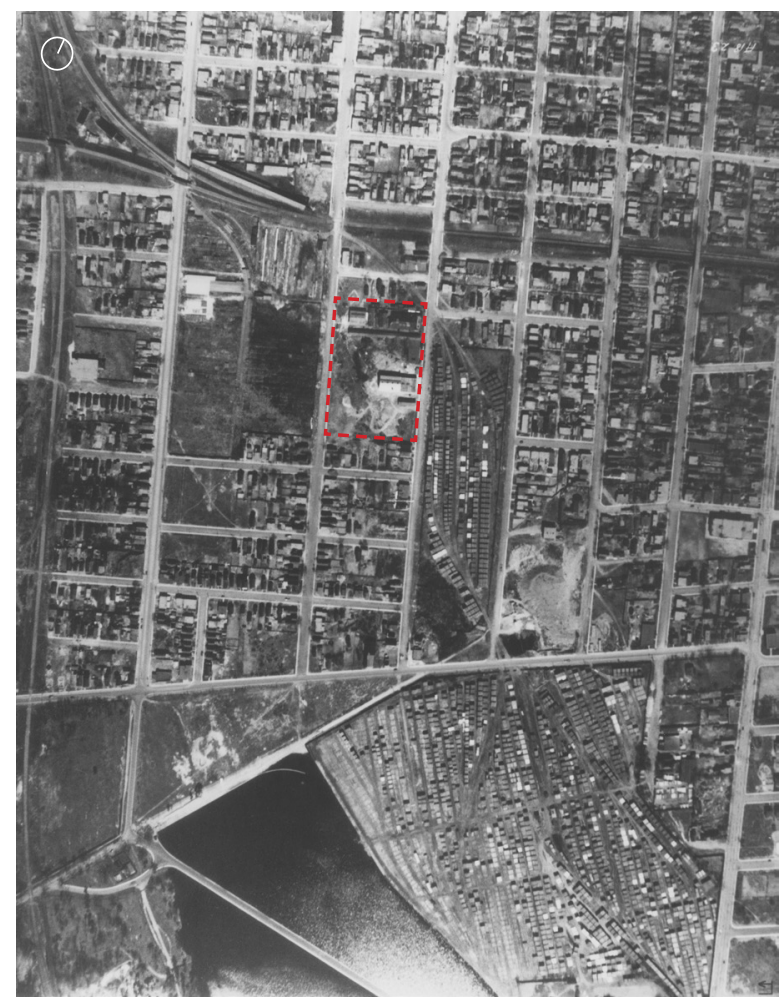

3. Aerial Photograph of Dalhousie Ward, 1928

(University of Ottawa) 


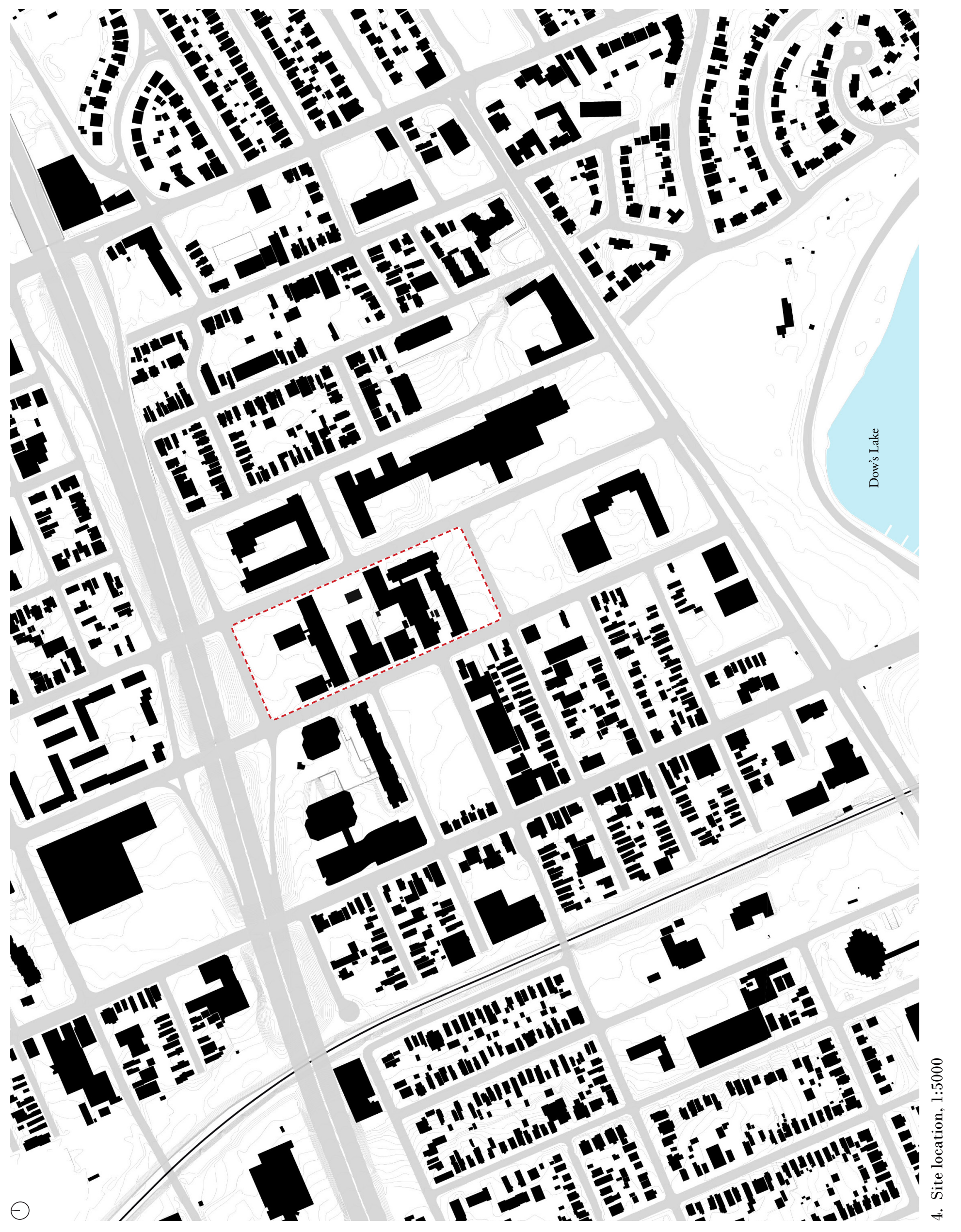




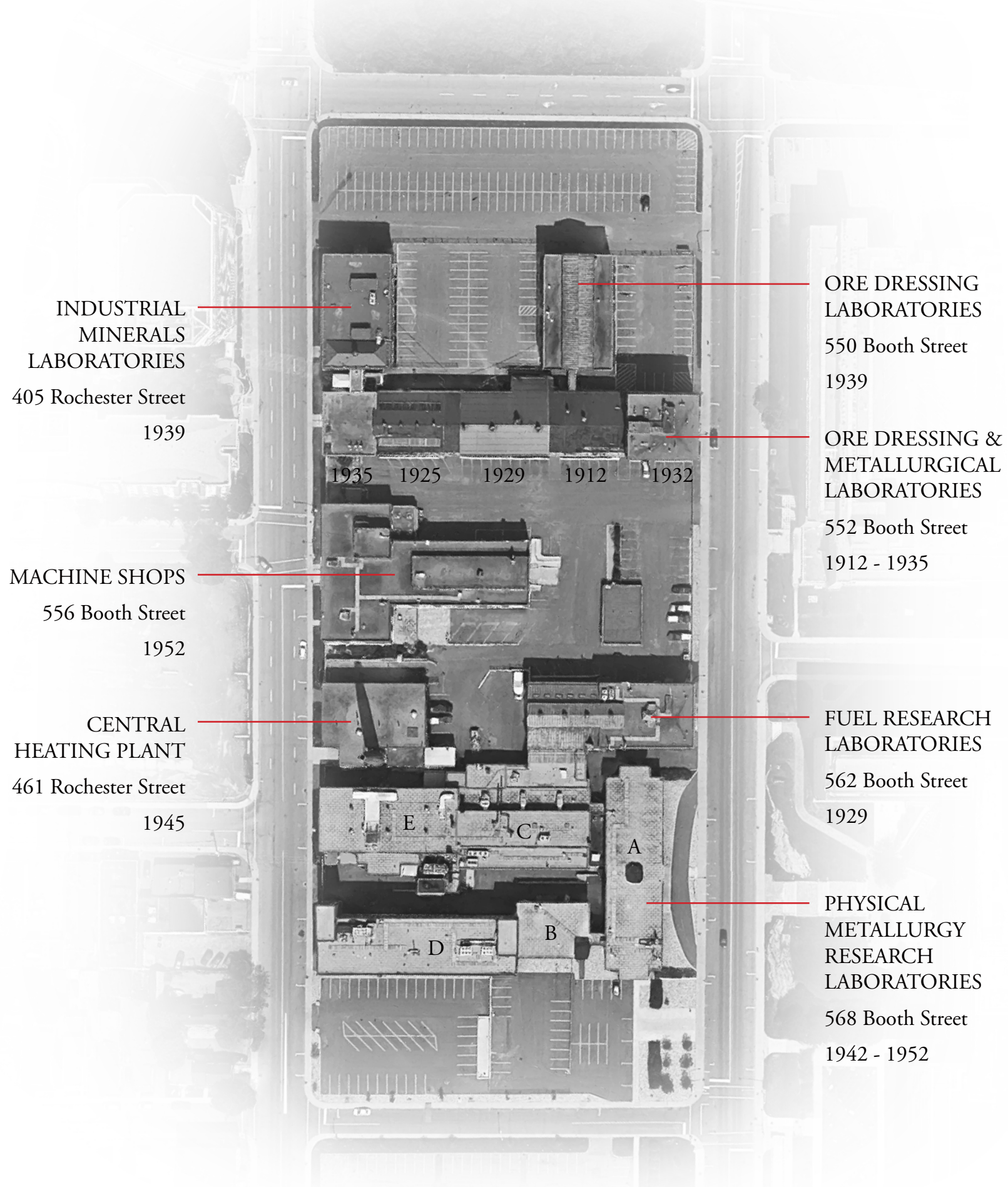


a way of "accelerating recovery, increasing employment and reducing the expenditures on relief," and provided funding for public buildings and infrastructure. After 1939 wartime constraints reduced the availability of steel products. Nevertheless, the construction of EMRC progressed due to its active role in the research and development of strategic materials. ${ }^{6}$ The 1946 Annual Report from the Bureau of Mines explains:

The urgent demands of the Armed Services made it necessary to expand and enlarge the facilities for metallurgical testing and research. This included the erection of a building to house the Physical Metallurgy Research Laboratories, in which were handled many hundreds of investigations and thousands of routine tests for the Navy, Army, and Air Force, the British Admiralty Technical Mission, British Air Commission, Inspection Board of the United Kingdom and Canada, and the Department of Munitions and Supply. ${ }^{7}$

The accelerated growth of the Department of Mines resulted in a series of architectural alterations to accommodate changing programmatic requirements. The architecture embodies traces of numerous transformations and holds physical evidence alluding to the work that was once carried out there (figures $6,7,8$ ). 


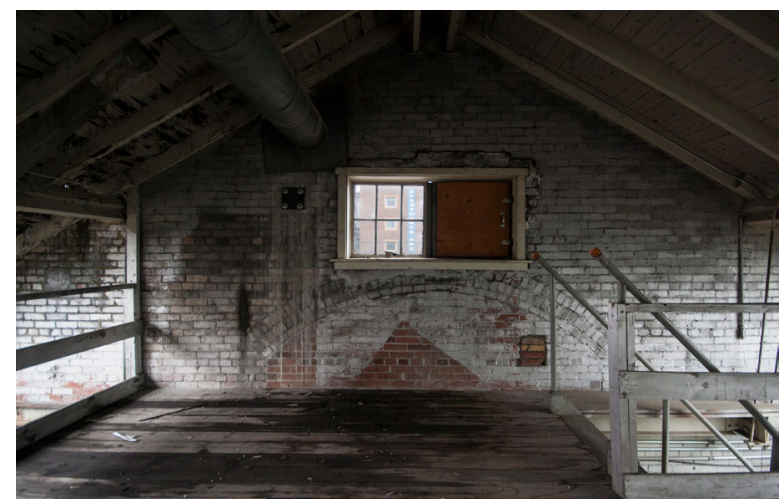

6. Ore Dressing \& Metallurgical Laboratories

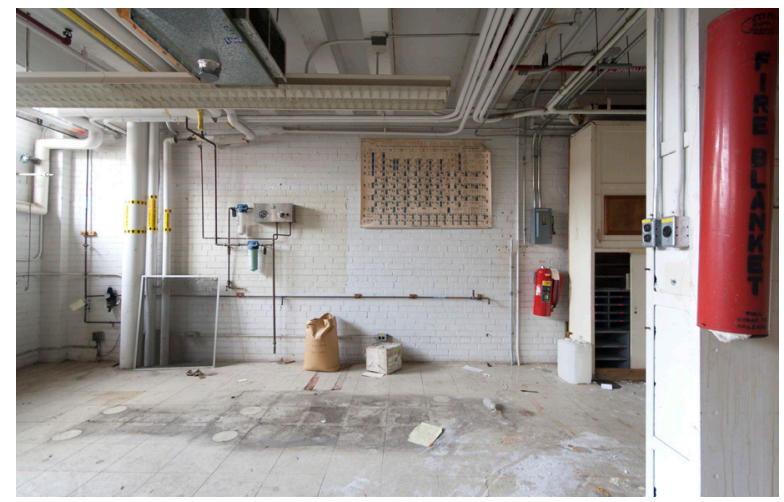

7. Fuel Research Laboratories

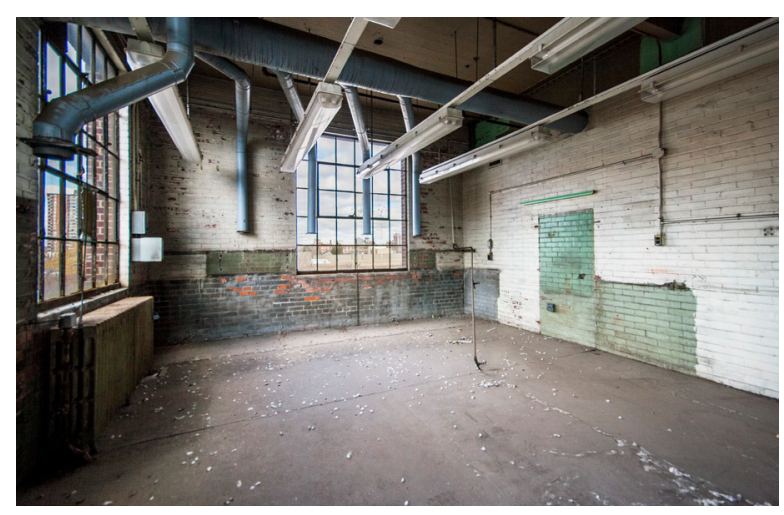

8. Ore Dressing Laboratories 


\section{A Part of Our Heritage}

The sale of the EMRC property-it closed on October 30, 2015-marks an important milestone in the life of the buildings. As the site is being transferred from Natural Resources Canada to Canada Lands Company for "strategic disposal," it is imperative that these federal heritage buildings be thoroughly documented before they are sold to private entities for redevelopment.

Although numerous government documents provide detailed guidelines for the conservation of heritage properties-including Canada's Historic Places' Standards and Guidelines for the Conservation of Historic Places in Canada (2010) and Parks Canada's Federal Heritage Buildings Review Office Code of Practice (1996)the buildings under private ownership are sometimes altered with financial concerns guiding the decision making process. Private organizations often implement heritage interventions which attempt to return buildings to their original state and dilute complex layers of historical alterations. 
One local example is Somerset House, built in 1900 and located in a Heritage Conservation District, under Part $\mathrm{V}$ of the Ontario Heritage Act, standing at the busy intersection of Bank and Somerset streets in Ottawa. The structure partially collapsed in 2007 when the building's owner began renovations without a building permit. This resulted in a six-year legal battle with the city while the building deteriorated. ${ }^{8}$ City council approved the design application in 2013 but it is unclear at this time whether or not construction has begun. The new design will supposedly "retain the heritage look of the building and add a contemporary addition to the northeast section," and does not show evidence of sincere consideration of the buildings' history. ${ }^{9}$

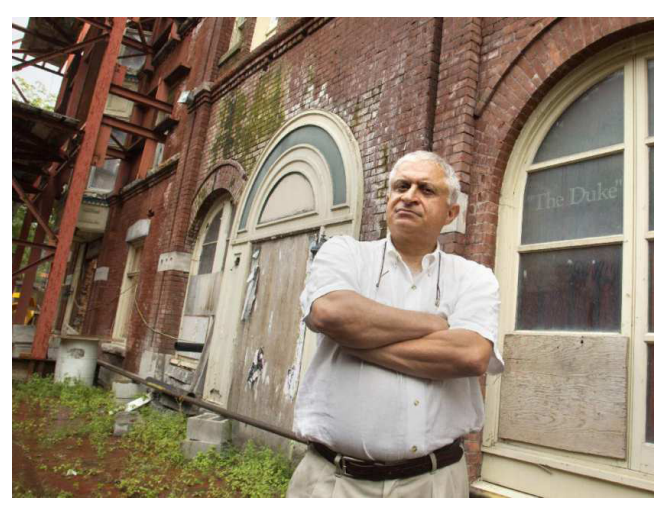

9. Somerset House and owner T. Shahrasebi (Ottawa Citizen) 
Through an access to information request I was able to obtain some information regarding Canada Lands Company's development concept for the property.

The project objectives are to: "optimize financial value for the Government of Canada through the management, development and timeline sale of the Booth Street Lands; create a mixed use development that conforms to the City of Ottawa's Official Plan; design a master planned development that enhances and is compatible with the surrounding land uses and community; have regard for the history of the site and encourage heritage acknowledgement, commemoration and/or preservation; carry out an open and transparent planning process including community consultation that provides opportunity for local residents and stakeholders to contribute to the redevelopment of the site; and secure development approvals in support of intensification and an increase in density to permit the appropriate and viable redevelopment of the site." 10 


\section{The extent of their commitment to heritage preservation}

is unclear due to portions of the requested information being withheld (figure 10).

\section{EXECUTIVE SUMMARY}

Canada Lands Company CLC Limited (CLC) has prepared the following Acquisition Business Plan to support the acquisition of the Booth Street Northwest and Central Quadrants (Booth Street) site and to demonstrate the ability to enhance the value of the site, while having regard for federal, municipal, community, and stakeholder interests.

The Booth Street site is a 2.55 hectare (6.5 acre) site of which Natural Resources Canada (NRCan) is the custodian. The site is located in Ottawa, approximately 2.65 kilometers southwest from Parliament Hill and it encompasses an entire city block and is bounded on all four sides by municipal streets. It is located in proximity to a mix of uses including high, medium, and low-density residential, office, retail uses, and an abundance of parks and open spaces. The site is occupied by residential, office, retail uses, and an abundance of parks and open spaces. The site is occupied by
seven buildings, six of which are obsolete and primarily vacant. The property includes a steam plant operated by Public Works and Government Services of Canada (PWGSC).

Five of the seven buildings have been designated as recognized by the Federal Heritage Buildings Review Office (FHBRO)
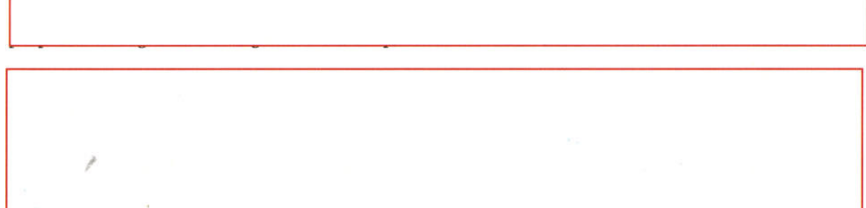

Based on the financial analysis, CLC is prepared to purchase the Booth Street property for an acquisition price $\square$ hile the site represents an excellent redevelopment opportunity, there are a number of significant considerations and risks that impact the financial viability of the redevelopment. In particular, the development of the site will 1

CLC believes that it will be able to, over the life of the project, generate value enhancement of approximately $\square$ from this transaction for the Government of Canada. In addition, CLC will provide for the creation of a new vibrant community in Ottawa that recognizes the historical significance of the site and adds lasting value for future generations of Canadians. The sale of this

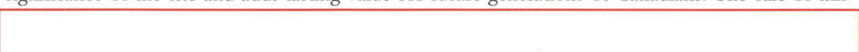

October 2013

s18(b), 21(1)(d),

$18(\mathrm{~d})$,

Page 1

10. Booth Street Acquisition Business Plan

(Canada Lands Company, A-2015-002) 


\section{New Modes of Preservation}

Rather than the limited approaches of preserving the outside appearance of buildings-often known as "façadism," which may reduce buildings to a narrow representation of history-Material Memory proposes a more in depth estimation of the complex through various techniques of making.

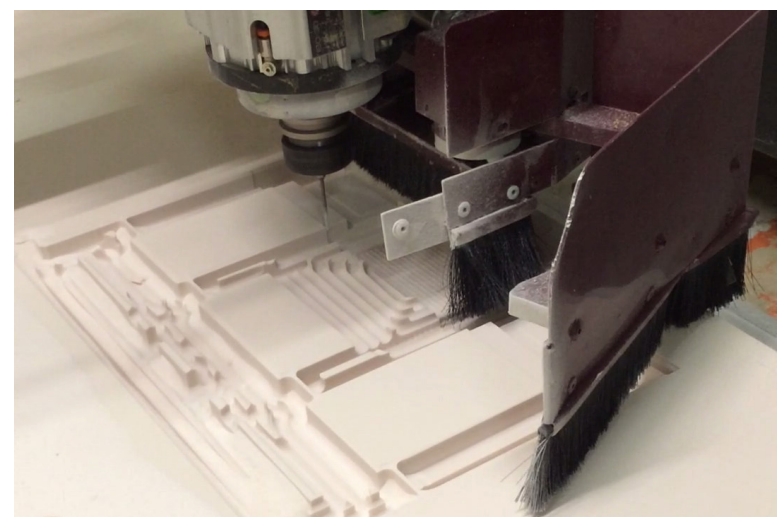

11. CNC milling

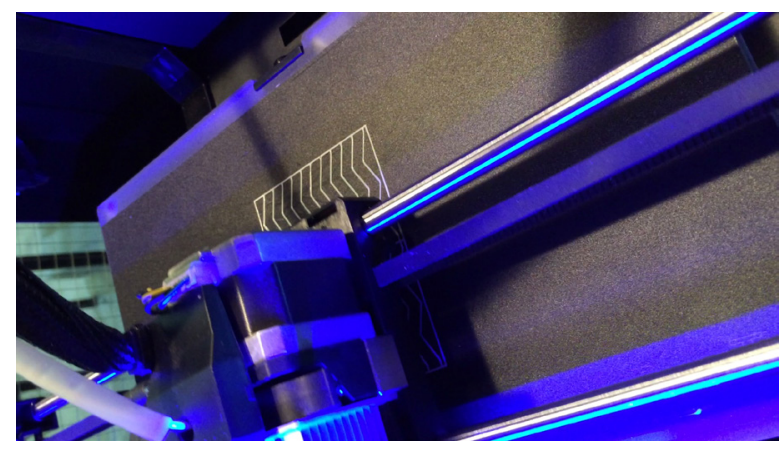

12. $3 \mathrm{D}$ printing 


\section{Science and Craft}

At the outset of this project, prior to the federal election in October 2015, Canada's cultural climate was one where science had been devalued by a government that forbid scientists from speaking publicly and cut crucial research funding. ${ }^{11}$ Canada's policies on scientists and scientific research seem to be improving with the Liberal government's 2016 budget providing new investments to promote scientific research. ${ }^{12}$ They also plan to create a new position of chief science officer "who will ensure that government science is fully available to the public, that scientists are able to speak freely about their work, and that scientific analyses are considered when the government makes decisions." 13

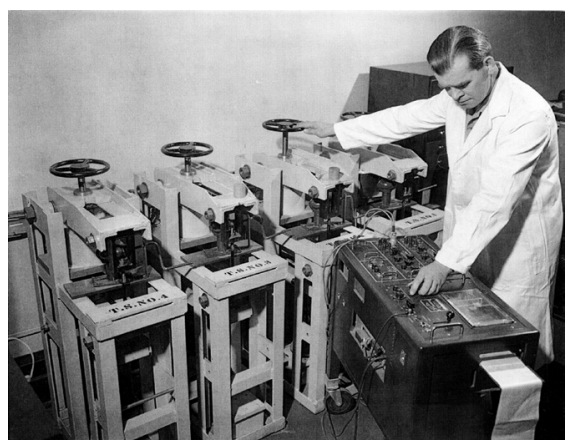

13. Scientist at 568 Booth St., 1956

(City of Ottawa Archives) 
Globalisation has changed Canadian socioeconomic trends, increasing the population's consumption of mass-produced goods that are often imported. This project seeks to re-valorize the traditions of science and craft which were once an integral part of our Nation's identity. Although research is focused on the Energy, Mines and Resources Complex and its significance as a narrative of Canada's material and industrial history, it joins international discussions of heritage conservation and provides new alternatives for reimagining the futures of urban industrial complexes and governmental sites.

Material Memory demonstrates the buildings' significance as a narrative of Canada's material and industrial history through archival research, materials studies, and the creation of a physical archive of the complex and the artefacts located therein. 


\section{Thesis Question}

How can rerepresentation deepen our understanding of place and provide means for reimagining the futures of urban industrial complexes and governmental sites? 


\section{Chapter 2: Preservation}

"All over the world, historic centers are being sanitized of signs of age and decay, losing any sense of the identity that buildings accumulate over time. Facades are carefully scrubbed clean; interiors, often blending minimalist white walls and a few painstakingly restored historic details, are reduced to a bland perfection." 14

- Nicolai Ouroussoff

\section{Preserving the Banal}

In today's social and economic framework, preservation has a direct impact on development. For example, if a site is designated as a UNESCO world heritage site, tourism will inevitably commence, sparking development and the inevitable "merchandising of history." Preservation and development are no longer opposing forces but synchronous forces, "preservation [...] is likely to lead to gentrification, and gentrification in turn is likely to ignore the bawdiness and diversity that lends to the inherent aura of the city itself." 15 
The EMRC site is at risk of becoming a powerful force in the ongoing gentrification of the Centretown West neighbourhood. In the once working-class area, newly built and proposed condominium projects are driving out low-income residents and small businesses to make room for condo-owners and chain stores (figure 14).

The neighbourhood needs a hub, a place of exchange where community members can meet. Rather than becoming a contributing force for gentrification and social displacement, the site would become an anchor for the community, a place for meeting, learning new skills, and creating.

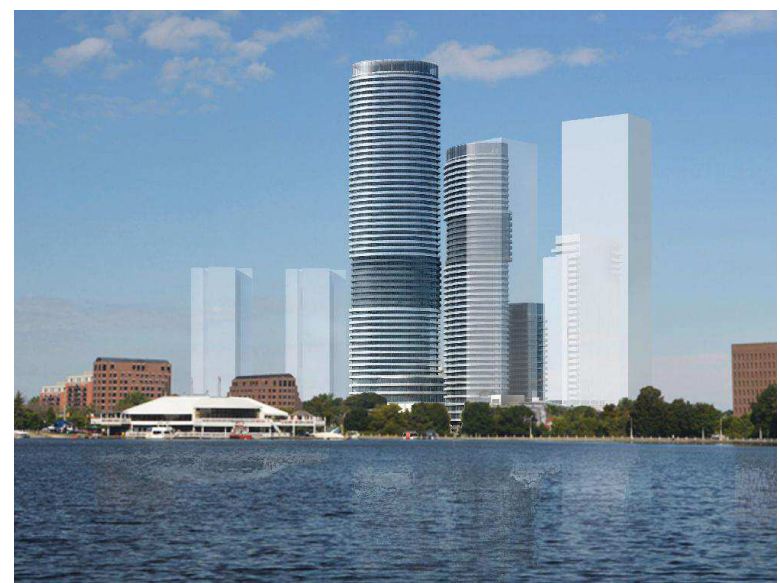

14. Future condos in Little Italy, Centretown West (Ottawa Citizen) 


\section{Inherent Character}

The design proposes to keep the layers of history intact and to emphasize them and their unique character (figure 15). This methodology combined with the new program will bring the dead site back to life, without contributing to gentrification.

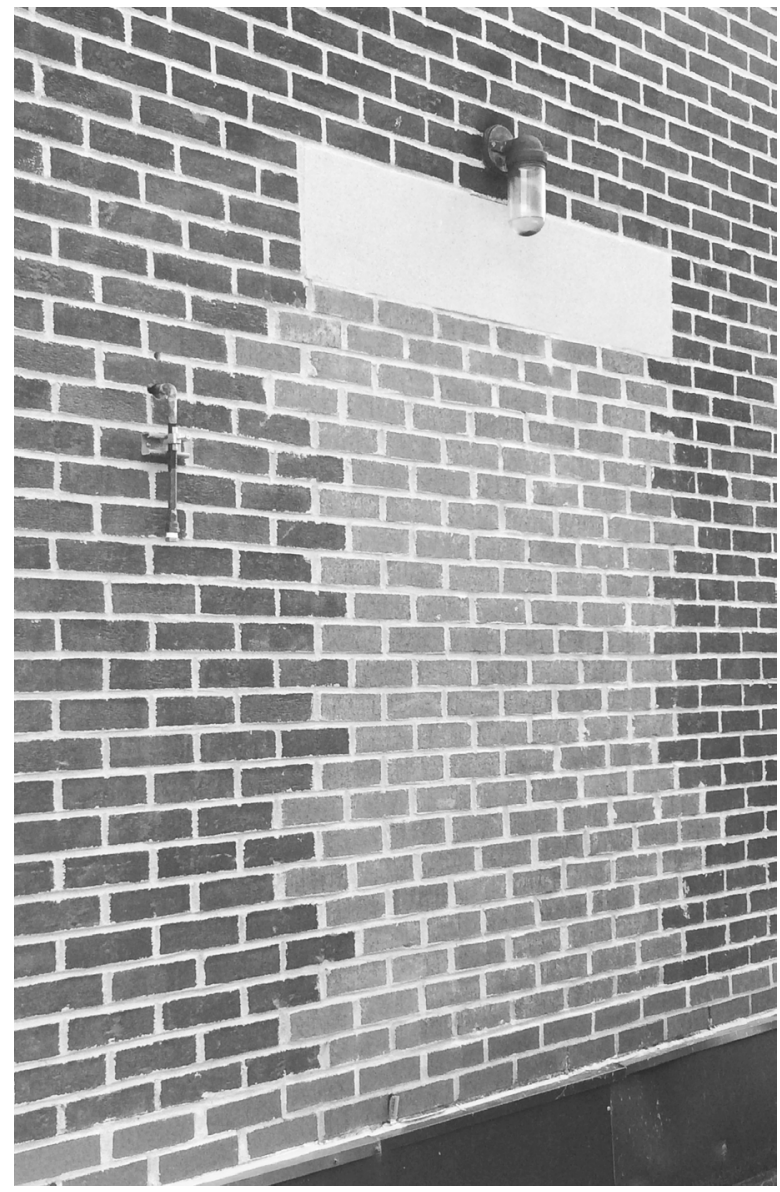

15. Evidence of alterations 


\section{Against Erasure}

Preference for the aforementioned historic erasure is evident in the Federal Heritage Buildings Review Office (FHBRO) Heritage Character Statement for the Ore Dressing Laboratories located at 550 Booth Street. Under the section entitled "Character Defining Elements," the report makes disconcerting recommendations regarding the principal façade facing Orangeville Street (formerly Lydia Street):

The entrance on this façade retains its stone surround, which is the only decorative element of the exterior, but the opening itself has been sealed closed with non-matching brick. When the opportunity presents itself, reinstatement of the former Lydia Street entrance would enhance the heritage character of the building. Restoring this as an operating entrance would reinstate both the visual and functional symmetry of the building by providing a symmetrically located point of entry. ${ }^{16}$

While it may be true that removing the non-matching brick which blocks the former principal entrance could enhance the building's functional symmetry, it would also erase a chapter of the building's history: specifically, evidence of a time when it was deemed preferable-for 
reasons unknown-to enclose the entrance. This ad hoc modification is just as much a part of the building's material history as any other brick. It is arguably worthy of the same preservation efforts as the classical stone surround (figure 16).

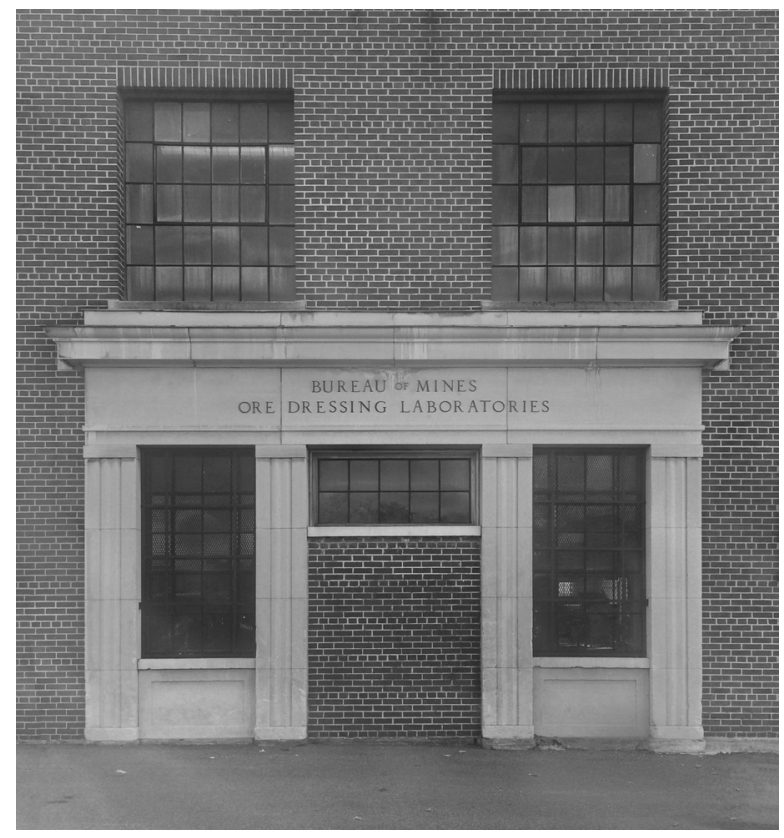

16. Ore Dressing Laboratories, North Facade 


\title{
Chapter 3: Representation
}

\begin{abstract}
"What could possibly be the advantages of abandoning the static view of buildings in order to capture them (through a theoretical equivalent of Marey's photographic gun) as a flow of transformations? One advantage would, of course, be that the divide between the "subjective" and "objective" dimensions could be abandoned. The other would be that justice could at last be paid to the many material dimensions of things."
\end{abstract}

-Bruno Latour \& Albena Yaneva

\section{The Problem with Representation}

This chapter highlights two dominant issues in the representation of buildings today. First, in the contemporary practice of architecture, buildings are typically represented as static objects, frozen in time. Second, the heritage value of a building is evaluated in a framework derived from the broad field of heritage conservation or based on direct comparisons with other buildings. Often, buildings are lumped together in groups and risk losing their singularity. 
In order to better document and describe the EMRC, this project considers each building as a unique, dynamic entity having passed through several historical or functional stages from site acquisition to project planning, from inhabitation to demolition. The heritage value of each building is assessed on an individual basis, going as far as to break down what appears to be a single building into its various parts which have different histories (figures $17,18,19)$.

\section{Individuality}

Spanish architect and philosopher Ignasi de Solà-Morales (1942-2001) offered a critique of contemporary methods of architectural representation in his book Differences (1996),

The topography of contemporary architecture is the pursuit of knowledge of architecture on the basis of its representation. Topography is the representation of place that reveals the knowledge of the place not as a type or class but as the place itself. Topography is geographical but it can also be architectural. Places are physical, but they can also be mental. Such places are particular, singular, and their description should not eradicate their individuality. ${ }^{17}$ 
Accepting Sola-Morales' definition of architecture as "an event resulting from the intersection of forces," 18 we can begin to see that no two projects or buildings are the same. Uncovering the intersecting forces (political, economic, and societal) allows one to begin evaluating the building in question as a unique individual.

Yet the buildings of EMRC are described in a way that eradicates their individuality. In fact, the Parks Canada online Directory of Federal Heritage Designations actually confused the images for the Ore Dressing Laboratories (550 Booth) and the Ore Dressing \& Metallurgical Laboratories (552 Booth).

The Ore Dressing \& Metallurgical Laboratories is a series of five interconnected buildings which were constructed at different periods (figure 17). However unjustly, the fourth addition is widely considered the most significant segment because it was designed by W.E. Noffke, the prominent Ottawa architect (figure 18).

In fact, the building description found in the on-line Directory of Federal Heritage Designations focuses 
entirely on the Noffke-designed portion of the building and makes no mention of the other four segments. The description states: "the building is a three-storey brick cube. Its restrained exterior decoration includes stringcourses and decorative pressed metal panels between the first and second floor windows." 19

To give the other four segments deserving degrees of respect and consideration, they should be considered as individual buildings, each with its own unique history. In-depth archival research allowed for me to gain a deeper understanding of the numerous changes made over time. The individuality of the five segments is accentuated through precise design interventions such as the creation of new openings where the segments are joined together (figure 19). 


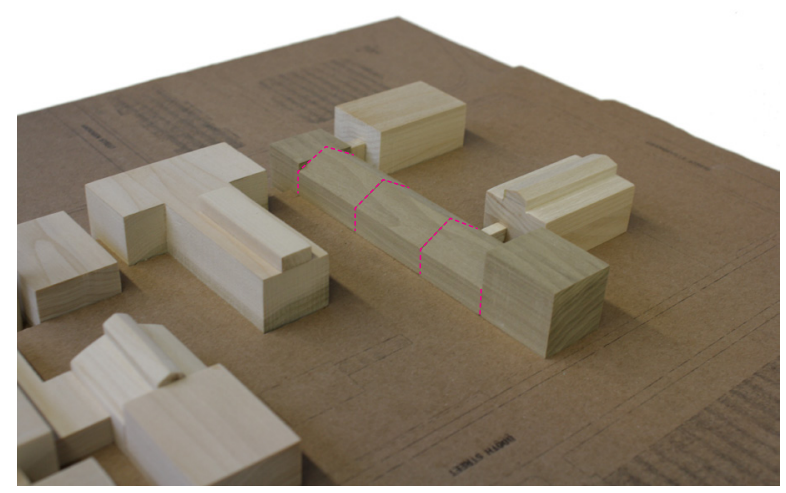

17. Massing model indicating individual buildings

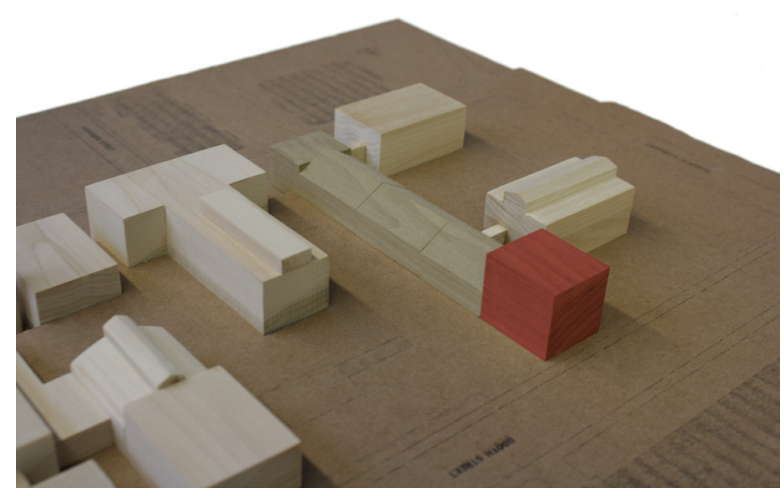

18. W.E. Noffke addition highlighted in in red

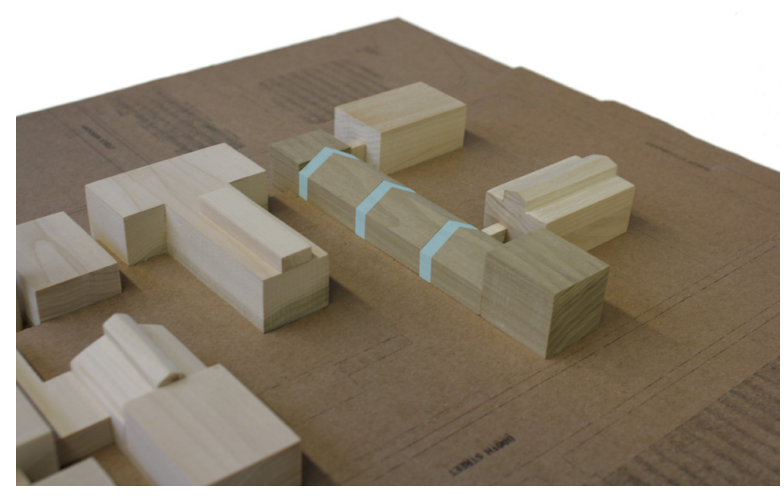

19. New openings shown in blue 


\section{Dynamism}

In their essay "Give Me a Gun and I Will Make All Buildings Move": an ANT's View of Architecture (2008), Bruno Latour and Albena Yaneva describe the difficulties of the representation of buildings as static objects: "it seems almost impossible to grasp them as movement, as flight, as a series of transformations." 20

To represent the buildings as a series of transformations I have made collages using architectural drawings from various periods of construction (figure 21). These are used as a backdrop for my intervention drawings to provide more context and to hint at the complex histories which are not immediately visible when looking at as-built drawings or the buildings themselves.

Considering the question of where the concept of buildings as static objects originates, Latour and Yaneva wrote, "it is probably the beauty and powerful attraction of perspective drawing that is responsible for this strange idea that a building is a static structure." 21 


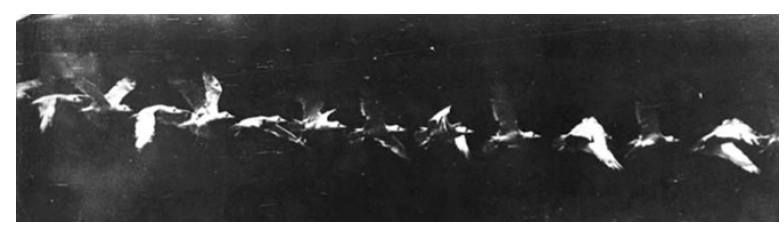

20. Étienne-Jules Marey, Bird in Flight, c. 1880s

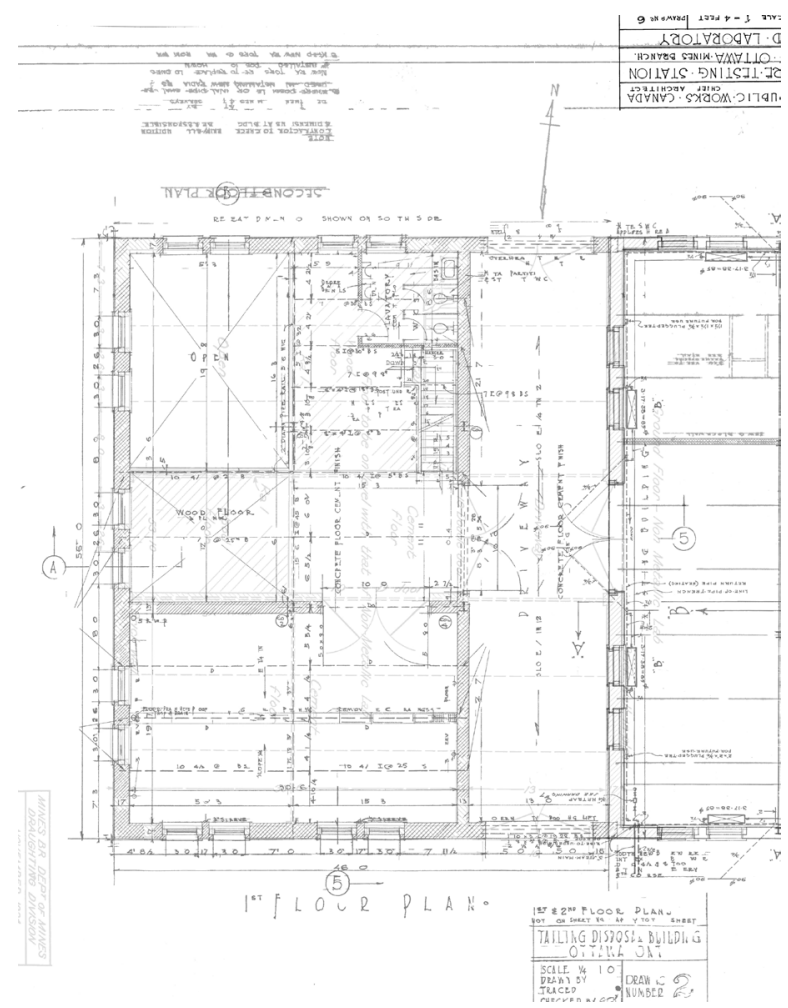

21. Collage, detail view 


\author{
Chapter 4: \\ Making Tools for Making Material History \\ "...for skin, not the soul, is our true organ \\ of memory." $" 22$ \\ - Betty Goodwin
}

\title{
Other Means of Preservation
}

The project draws on a combination of diverse research methods to achieve a thorough recording of EMRC and its profound history. These include archival research, oral histories, site mapping, architectural drawings, digital fabrication, and materials studies. This range of techniques-which explore the material, social, and scientific histories of EMRC-enables the creation of a historically rich representation of the complex and its unique architectures and challenges the typical reliance on perspective drawings as representation. 


\section{A Theory of Rerepresentation}

As a centre for industrial sciences, EMRC once contained a cement and moulding sand laboratory, road materials laboratory, microscopic laboratory, ceramic laboratory, kiln room, plaster and gypsum laboratory, fuel testing laboratory, ore testing laboratory, grinding and polishing room, metallographic laboratory, electrolytic laboratory, chemical laboratory, constant temperature room, plastic deformation laboratory, carpenters' shop, machine shop, welding shop, blacksmith shop, tinsmith shop, carbonization laboratory, oil research laboratory, gas research laboratory, metal forming laboratory, melting and smelting laboratory, sand-casting laboratory, sintering room, machinability testing workshop, dark rooms, plates and sample archives, libraries, and reading rooms. The buildings still contain some of the tools and machines once used for making materials which significantly contributed to Canada's material and industrial history. 
The needs of industrial science at EMRC stimulated the hands-on approach to materials research as a technique of architectural design. The aim is to discover how varying modes of rerepresentation can be utilised as a means of architectural conservation and a vehicle for the creative expression of unique features.

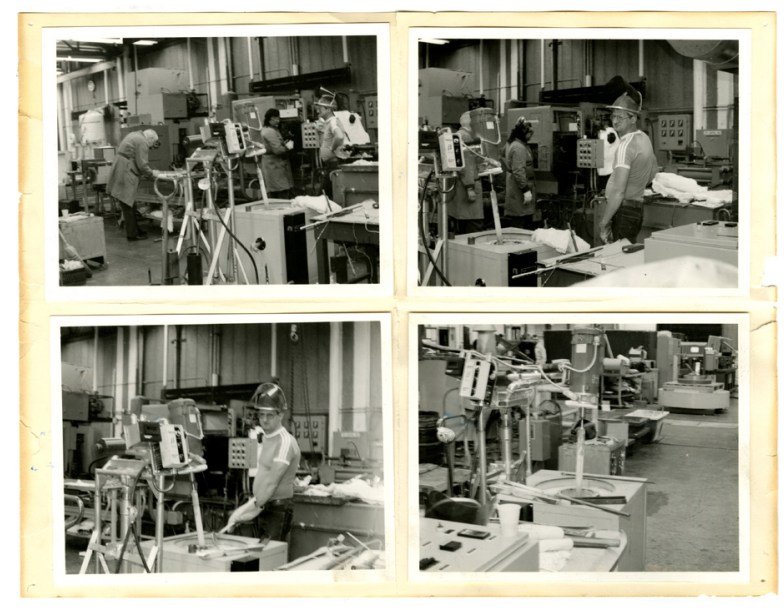

22. Photographs of employees and machinery (Recovered from 562 Booth Street, 10/2015)

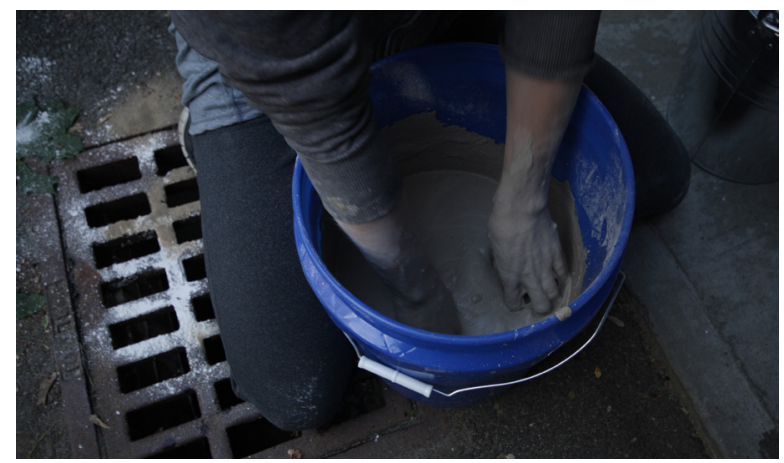

23. Making the backyard foundry 
This thesis defines rerepresentation as a form of representation that articulates rather than depicts, reveals complexities, and unveils new possibilities for design interventions. As a method of making, rerepresentation usually results from a process involving a series of steps, and through these steps complexities and opportunities are brought to light.

Case studies of artists Betty Goodwin and Rachel Whiteread focus on techniques of making. Their work shares a focus on expressing the memory of a place or object through varying modes of rerepresentation such as castings, etchings and drawings.

Formal typological studies will be utilized to learn from the structures themselves through digital and physical remodelling as a means to imagine an alternative future for the abandoned industrial site. 


\section{Artist Case Studies}

Montreal-born artist Betty Goodwin (1923 - 2008) used the mediums of printmaking, drawing, and sculpture to explore the materiality of found objects and spaces. She uncovered "histories and innate characteristics" to reveal "traces of life." ${ }^{923}$ Whether a sheet of paper or a floor, surfaces were a reoccurring medium for Goodwin, who; through a method of adding and removing; sought to reveal memories which would either be erased or developed by future interventions. ${ }^{24}$

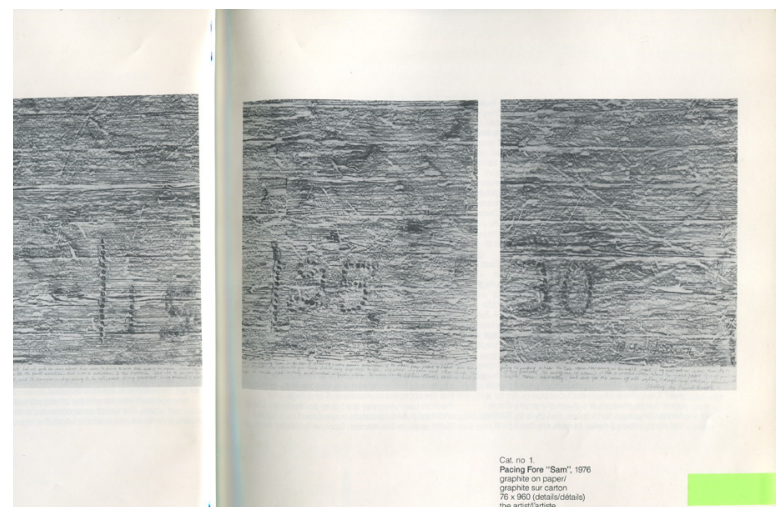

24. Betty Goodwin, Pacing Fore "Sam", 1976

(Betty Goodwin: Passages, 1986) 
The large-scale sculptures of Rachel Whiteread take the form of castings of carefully selected found objects and spaces. Whiteread is dedicated to preserving all imperfections and human imprints, "retaining the minutia of surface detail. ${ }^{925}$ Her dedication to the honest rerepresentation of objects is a constant theme throughout her work and exemplifies her "almost scientific interest in the trace left by body and an obsession with the specific place and community." ${ }^{" 26}$ Whiteread has made many works guided by a desire "to give a king of grandness" to "cheap post-war furniture"27 (figure 25).

Whiteread's sculpture for the fourth plinth at Trafalgar Square in London is a horizontal mirror image of the plinth itself, cast in clear resin. Thematically, the piece touches on the notions of doubling and overlapping old and new by juxtaposing two materials with inherently opposite qualities. Visually, the water-clear resin cast is a very light addition, seemingly floating above the granite plinth. 


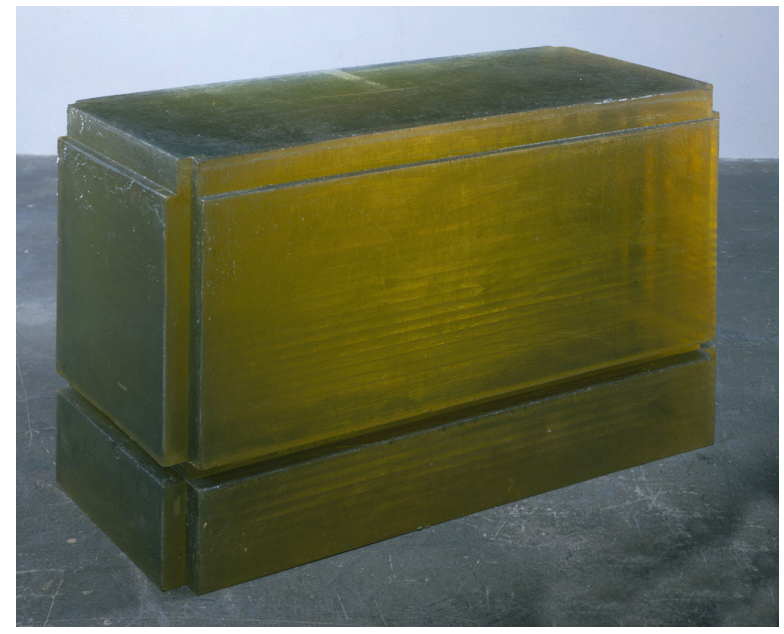

25. Rachel Whiteread, Untitled (Chair), 1993

(www.gagosian.com)

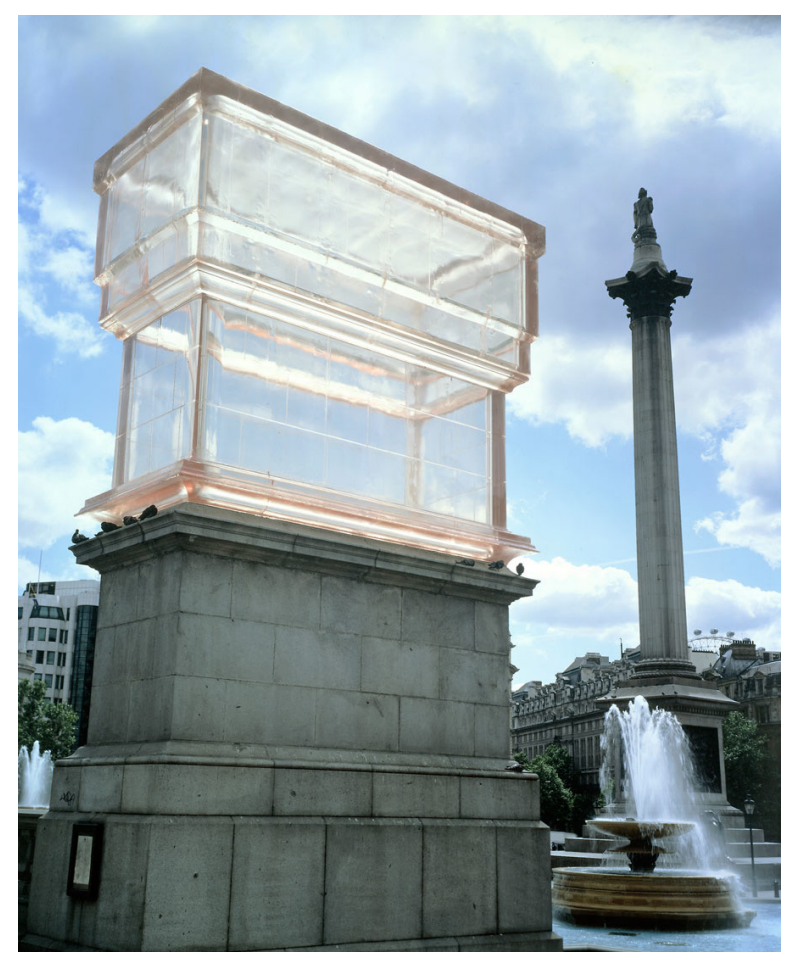

26. Rachel Whiteread, Monument, 2001

(www.gagosian.com) 


\section{Human Traces}

The types of human traces that Whiteread and Goodwin seek to reveal permeate EMRC. Through rerepresentation I aim to raise the status of those marks made by humans over time, focusing on surfaces and remnants. To emphasize further the significance of the traces, the scale and material for the rerepresentations will be carefully considered.
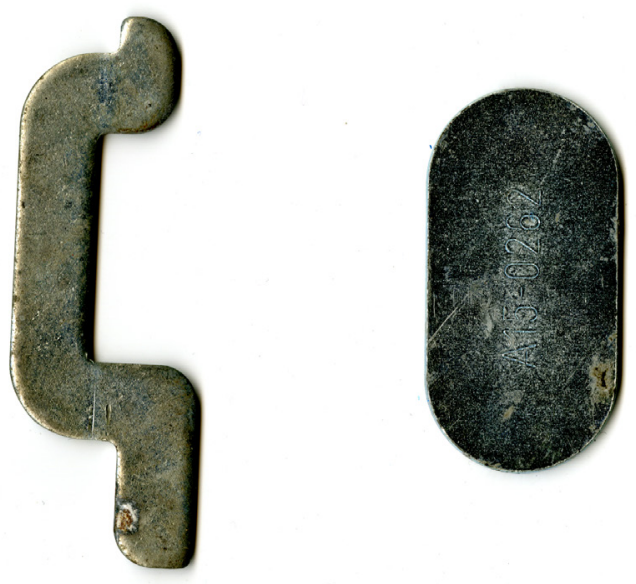

27. Alumium samples, date unknown

(Recovered from 568 Booth Street, 10/2015) 


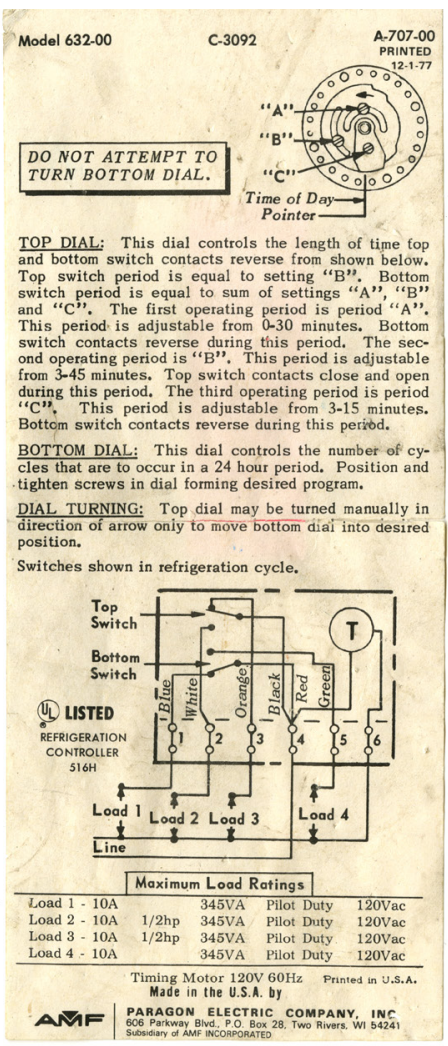

28. Various signage, dates unknown

(Recovered from 568 Booth Street, 10/2015) 
As a study of material history, seeing the modelling process through from beginning to end-including fabricating tools which would later be used to create parts of the archive-became a significant aspect of the project. Philosopher Peter Kropotkin suggested, "None but he who knows the machine-not in its drawings and models only, but in its breathing and throbbings-who unconsciously thinks of it while standing by it, can really improve it." ${ }^{928}$

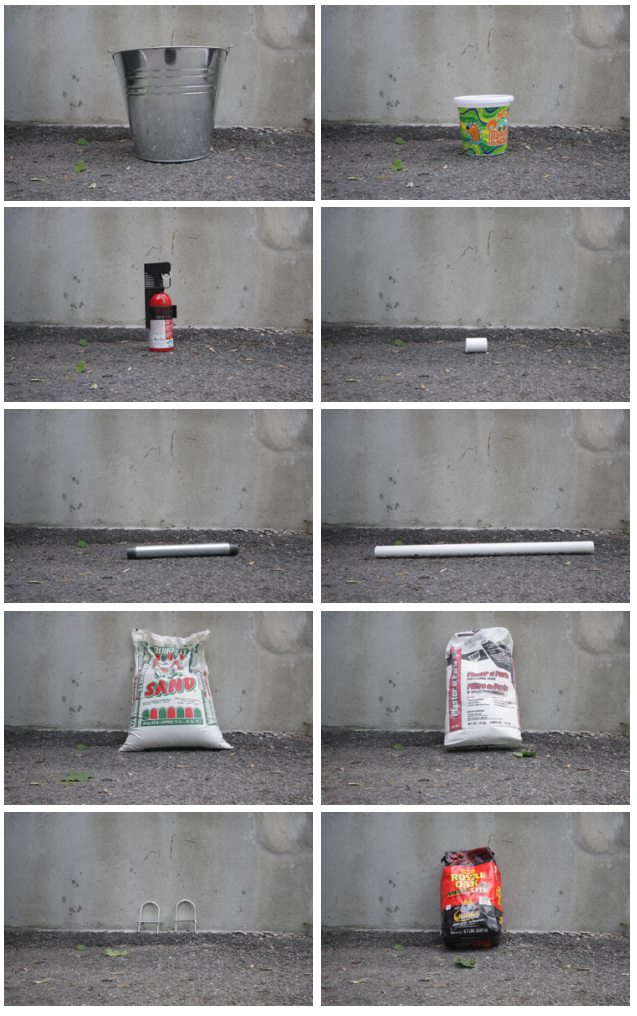

29. Materials for making the foundry 


\section{The Foundry}

The backyard foundry was constructed in order to explore the manufacturing technique once used by EMRC. This low-tech foundry gets hot enough to melt scrap aluminium for casting (figures 30, 31).

The molten aluminum is poured into a muffin pan to form pure aluminum ingots, removing any impurities in the process. The ingots are then melted down to pour the final casting.

The first sand-casting attempt utilized the "lost foam" technique in which a foam positive is surrounded by sand, and gets replaced by solid aluminum through the casting process. Although the first attempt (figure 32) was not entirely successful, I am now better prepared for the next attempt after visiting the Merrickville Alloy Foundry and learning the various casting techniques. 


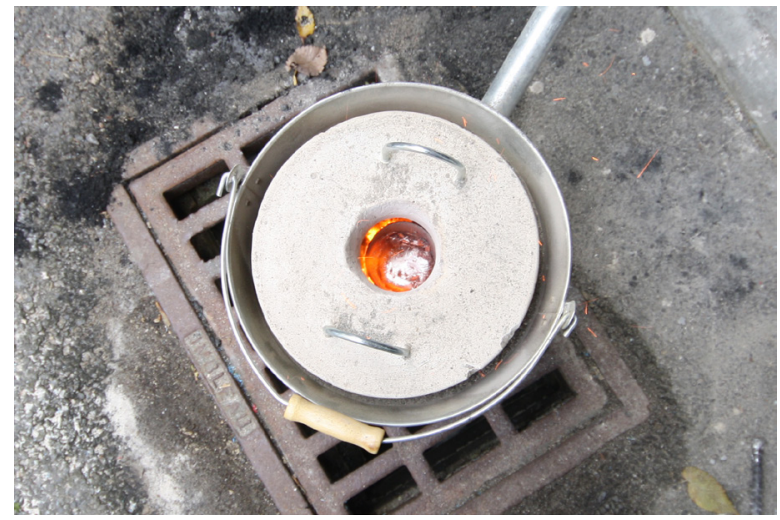

30. The foundry, melting aluminium cans

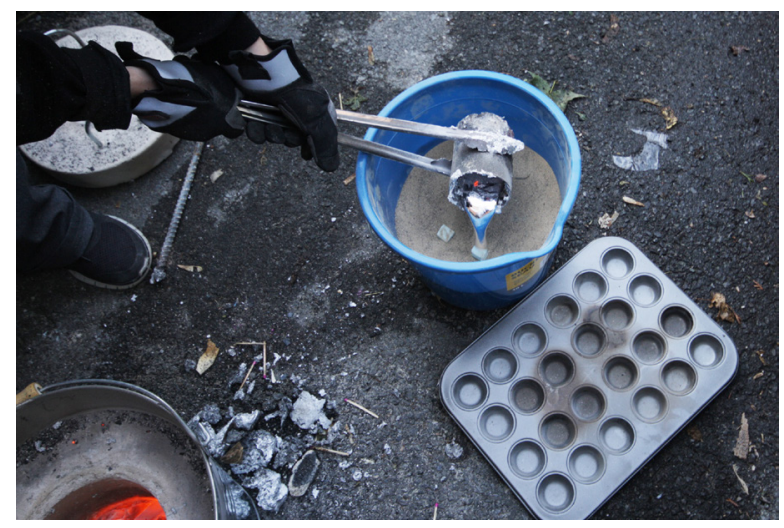

31. Lost foam sandcasting, first attempt

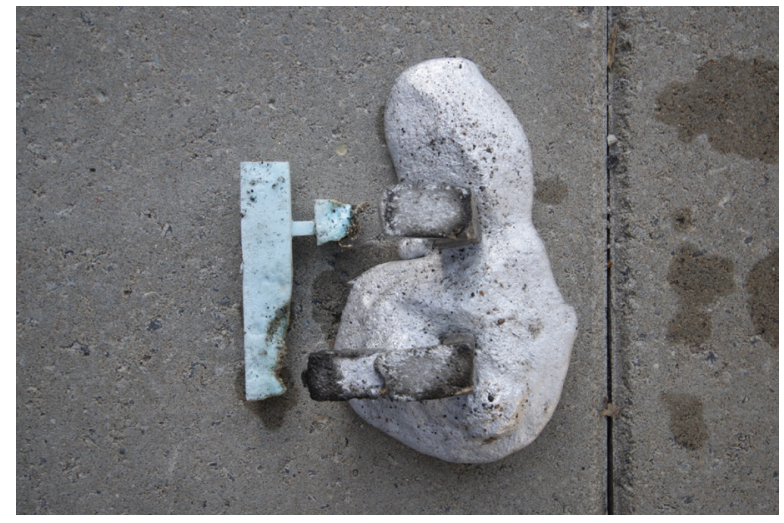

32. Incomplete lost foam casting 


\section{Casting Rockite}

The North façade of the Ore Dressings Laboratories (550 Booth Street) was selected for rerepresentation because of its curious appearance; what was once the primary entrance to the building is now bricked-in. This is a more obvious example of the human traces left on a building over time. As discussed in chapter 2, the FHBRO Heritage Character Statement for 550 Booth Street suggests that the former primary entrance should be reopened. Removing this brick wall would erase part of the building's complicated history. I selected this façade for rerepresentation to draw attention to it, in hopes of compelling viewers to consider the historic significance behind the filling-in.

The first step was to convert a two-dimensional image into a three-dimensional computer model. The CNC router (computer controlled cutting machine) then cut the 3D form from a block of high-density polyurethane foam to create a detailed mold. This casting was made using Rockite cement. 


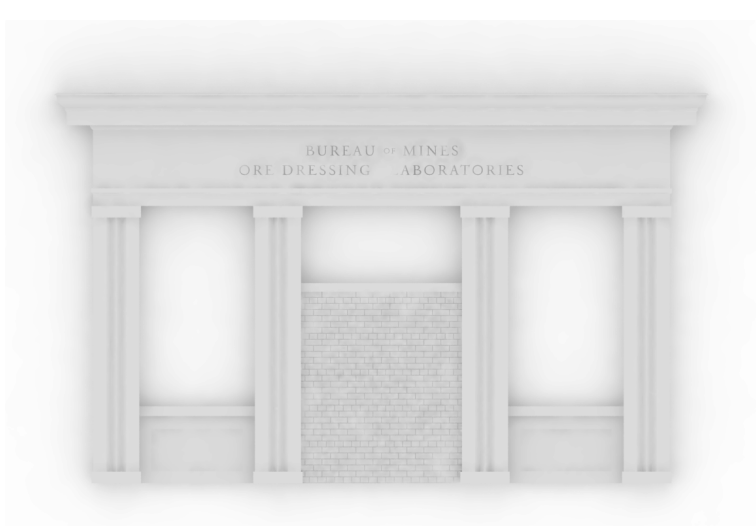

33. 3D model

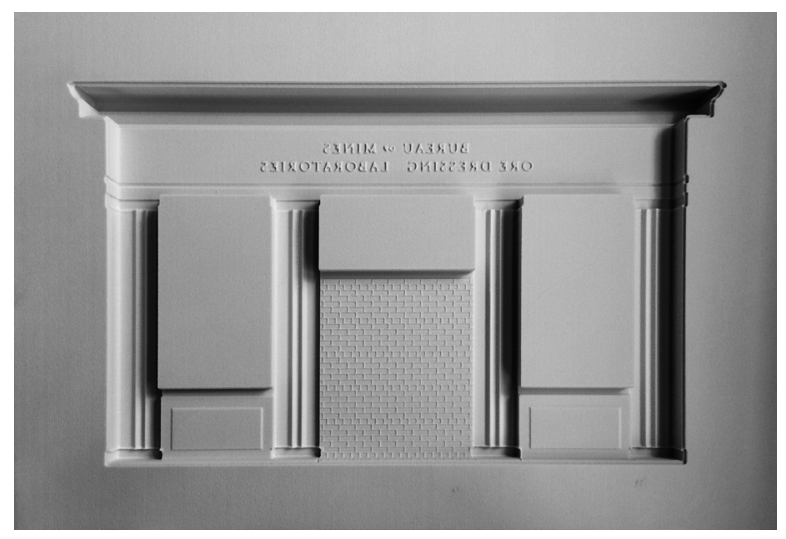

34. CNC-cut polyeurethane foam mold

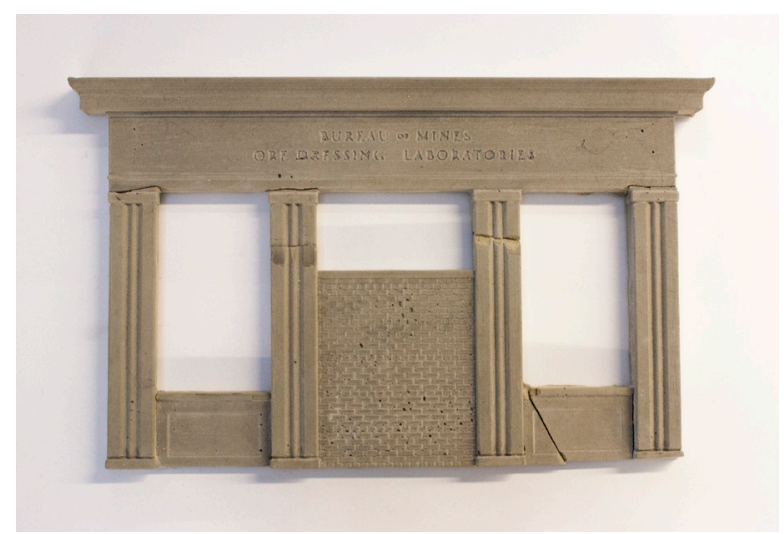

35. Rockite casting 


\section{Casting Plaster}

The "Brick Seam" model highlights significant evidence of historic alterations of 552 Booth Street. What appears to be a single building is in fact a series of 5 buildings that were linked and added-on over time, forming a whole. The plaster model represents the intersection of where Building 2 once ended and Building 5 was added in $1935 .{ }^{29}$ In essence, it captures a significant moment in time as concrete evidence of the rapid growth of EMRC.

The model was made through a four-step process. A photograph was scaled and converted to a vector drawing that was then laser-etched onto a sheet of acrylic. The acrylic positive was used to make a silicone mold into which plaster could be poured to achieve the final rerepresentation. 


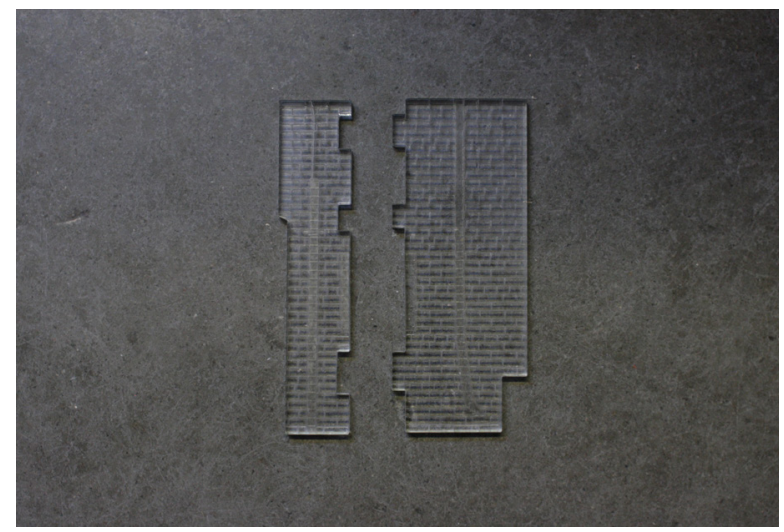

36. Laser-cut acrylic models

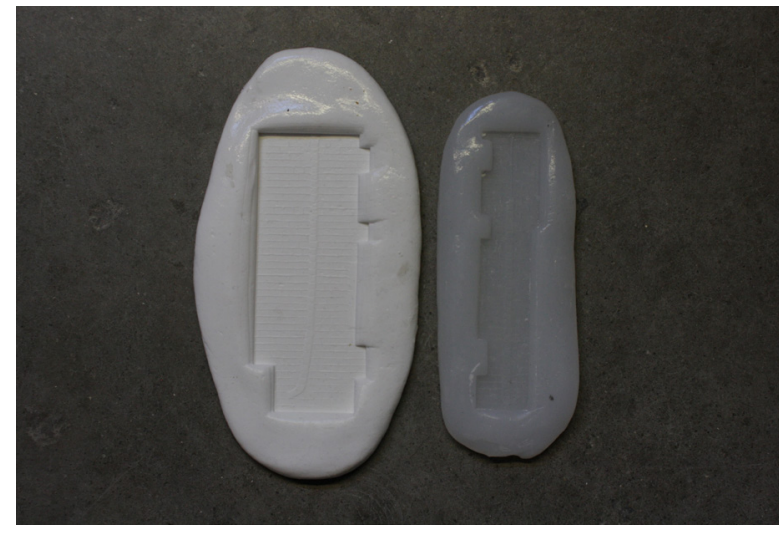

37. Silicone molds

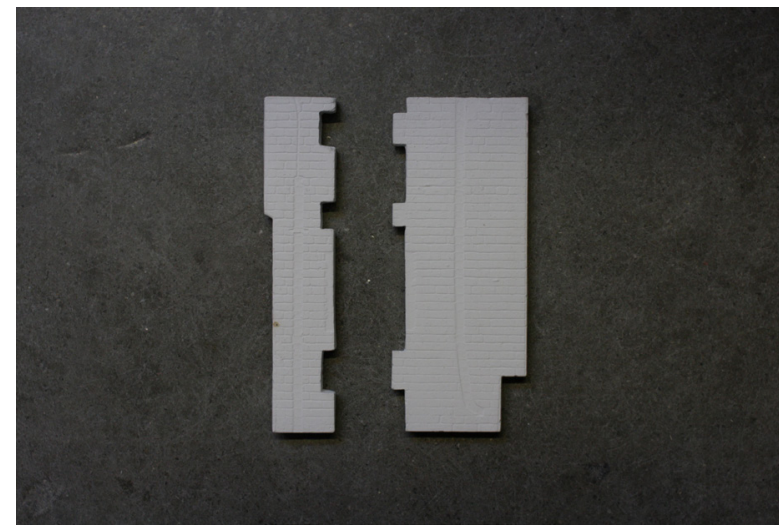

38. Plaster casting 


\title{
Chapter 5: Program
}

\begin{abstract}
"Be it handicraft, science or art, the chief aim of the school is not to make a specialist from a beginner, but to teach him the elements of knowledge and the good methods of work, and, above all, to give him that general inspiration which will induce him, later on, to put in whatever he does a sincere longing for truth, to like what is beautiful, both as to form and contents, to feel the necessity of being a useful unit amidst other human units, and thus to feel his heart at unison with the rest of humanity." 30
\end{abstract}

\section{- Peter Kropotkin}

\section{The Benefits of Manual Work}

The EMRC was once a state-of-the-art research complex. It made significant contributions to international scientific research and the Canadian economy. At one time, the complex was producing specialty parts for Ford and General Motors, as well as for the Canadian Space Agency. When its clients began outsourcing manufacturing to foreign countries to cut costs, ERMC suffered. 
As globalization has created trends of increased consumerism, the daily lives of Canadians have been affected in many ways. Only a few generations ago, many people would have had some practical skill such as sewing, weaving, woodworking, or blacksmithing. As society has become more and more dependent on technology and inexpensive consumer products we have begun to lose touch with our instinct to make, forgetting that, "to be human has been, for time immemorial, also to labor, to produce the goods one needs to live." 31 Today, many rely on others to provide goods and services that they were once able to provide for themselves, "what ordinary people once made, they buy; and what they once fixed for themselves, they replace entirely or hire an expert to repair, whose expert fix often involves installing a premade replacement part." 32

This decrease in practical skills can also be attributed to the modern education system where a clear separation has been made between manual work and cognitive work. Although written in the late nineteenth century, Peter Kropotkin's Fields, Factories and Workshops Tomorrow 
(1974) presents compelling arguments for abolishing the division of manual work and "brain work" which remains predominant in today's society. He advocated the "education intégrale," arguing that the reunion of handicraft and scientific knowledge within education; eliminating the separation of thinking from doing; has many benefits for both the individual and society. Kropotkin suggested that abolishing the distinction between brain workers and manual labourers would reduce social conflicts. He also wrote of the "...fullness of life which would result for each separate individual, if he were enabled to enjoy the use of both his mental and bodily powers..."933

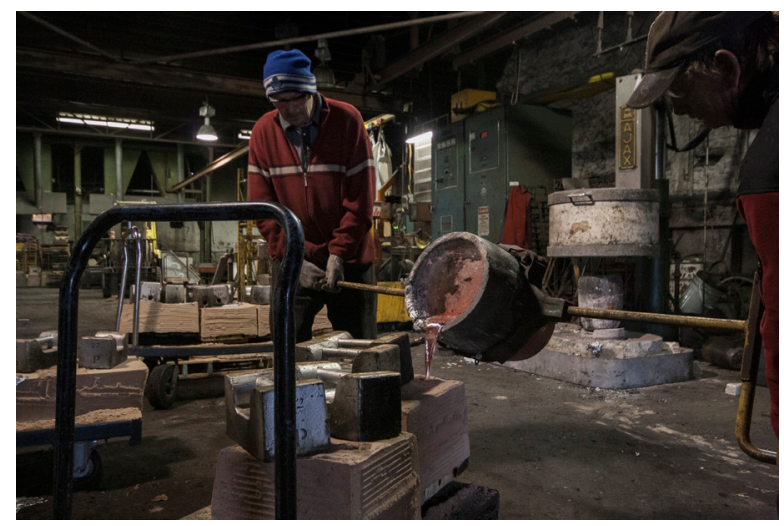

39. The Merrickville Alloy Foundry 
This philosophy is still being explored in contemporary popular culture. Matthew Crawford, a popular author with a Ph.D. in political philosophy celebrates the benefits of making things in his book Shop Class as Soulcraft (2009):

Hobbyists will tell you that making one's
own furniture is hard to justify economi-
cally. And yet they persist. Shared memo-
ries attach to the material souvenirs of our
lives, and producing them is a kind of com-
munion, with others and with the future.

The educational component of the program provides citizens with new skills and the ability to be critical of and, "think materially about material goods," giving them renewed autonomy and resistance to the manipulations of advertising. ${ }^{35}$ The program provides spaces where people can learn and practice a craft, and produce meaningful objects and memories. 


\section{Generative Space}

EMRC should be returned to a state of productivity. It is of course unrealistic for the buildings to continue to house laboratories. The Federal Government has after all deemed the buildings as surplus; moreover, Ottawa's industrial sector has shifted to the outskirts of the city where real estate costs are much lower. Yet the raw, industrial spaces — "designed to accommodate the heavy equipment and machinery required to carry out research studies in fuels and metallurgy" in "open work-areas with high ceilings" —offer powerful opportunities for recuperation and reuse. It would be a missed opportunity if the buildings were used for mixed-use condominium projects. $^{36}$

By providing spaces for local communities to create and collaborate, the complex can become a social catalyst in Ottawa. The spaces take form as a post-secondary arts and crafts school, gallery, archive, business incubator, library, and community centre. 
Community members have access to spaces where they can rediscover their power to make. Specialised facilities include woodshops, metal shops, artists' studios for large-scale works, and workshops for ceramics, weaving, jewellery making and other skilled crafts. The buildings also house a gallery where creators may display their work.

The provision of generative space is a response to the act of preservation, allowing the site to achieve balance between the past and the future.

\section{The Archive}

The Archive provides space for the celebration and contemplation of EMRC's material history. Historic documents, artefacts recovered from the site, as well as large-scale installations highlight significant aspects of the complex's material history.

The artefacts, equipment, and demonstrations displayed have an engaging tactile quality, and are presented in a manner that is not contrived. Visitors are given agency to 
interpret the history of EMRC. Together, the architecture and the artefacts of the archive provide a comprehensive representation of the complex in order to deepen our understanding of place.

The archive aims to raise public awareness of the role EMRC played in the nation's material and industrial history, including its part in Ottawa's development as a capital city and diplomatic centre which resulted from "Canada's massive contribution of men and material to the war effort. ${ }^{" 37}$ Additionally the archive acts as a lens through which to contemplate the past and the future of the industrial site.

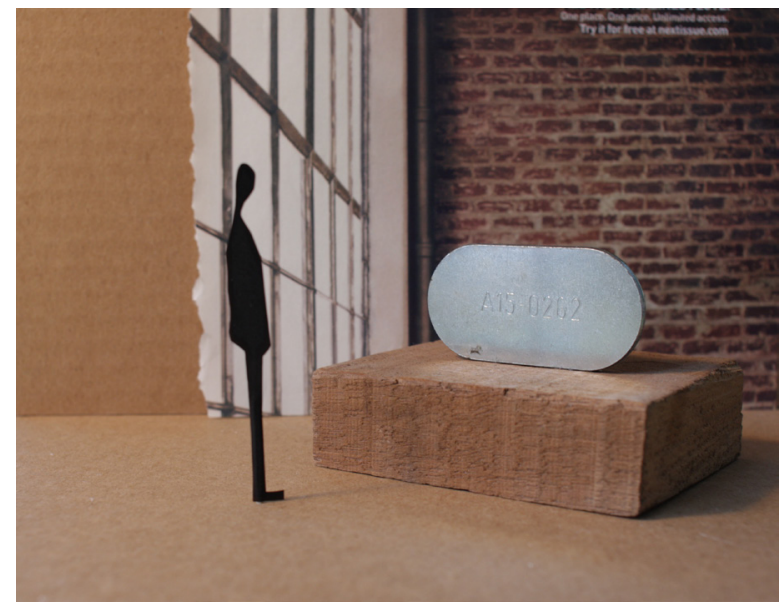

40. The Archive 


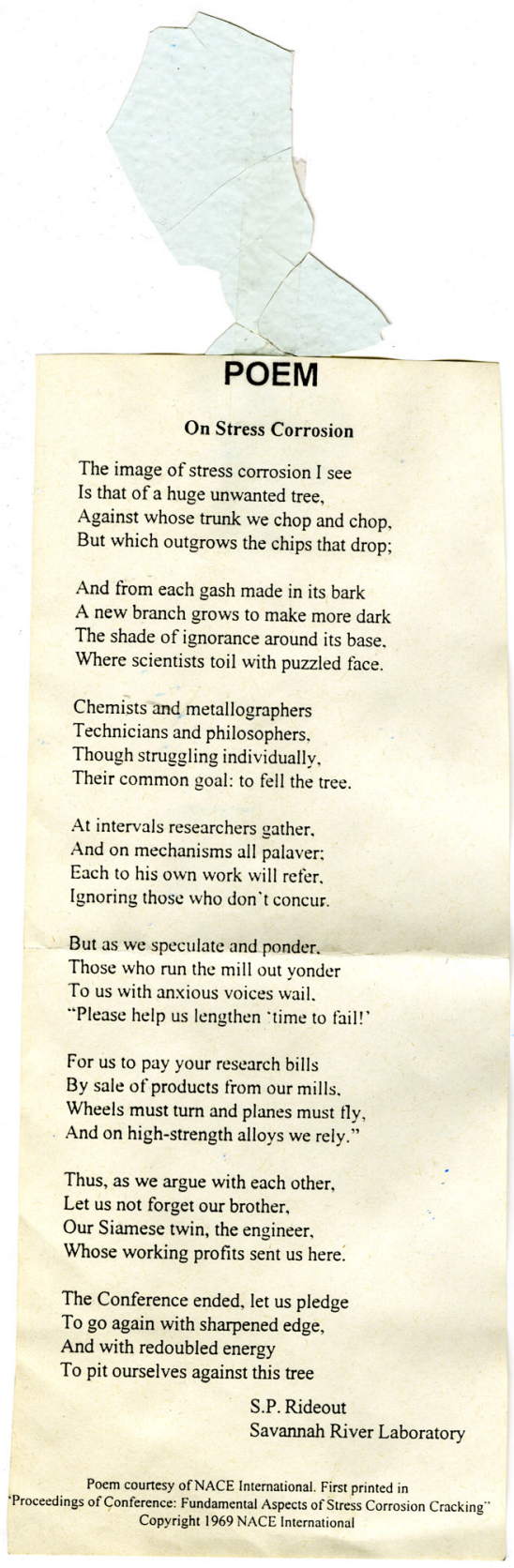

\section{Poem On Stress Corrosion, 1969}

(Recovered from the office of M. Elboujdaini) 


\title{
Chapter 6: The Architecture
}

\begin{abstract}
"The reality and reliability of the human world rests primarily on the fact that we are surrounded by things more permanent than the activity by which they were produced, and potentially even more permanent than the lives of their authors." 38
\end{abstract}

- Hannah Arendt

\section{Site Strategy}

The design proposal focuses the northern portion of the complex (figures 42,43), specifically the Industrial Minerals Laboratories (405 Rochester), the Ore Dressing Laboratories (550 Booth), the Ore Dressing \& Metallurgical Laboratories (552 Booth), and the Machine Shops (556 Booth). The design assumes that the other buildings of EMRC will remain so that the program can continue to grow and fill the empty spaces organically, in a similar fashion to how the complex grew throughout the early $20^{\text {th }}$ century. 


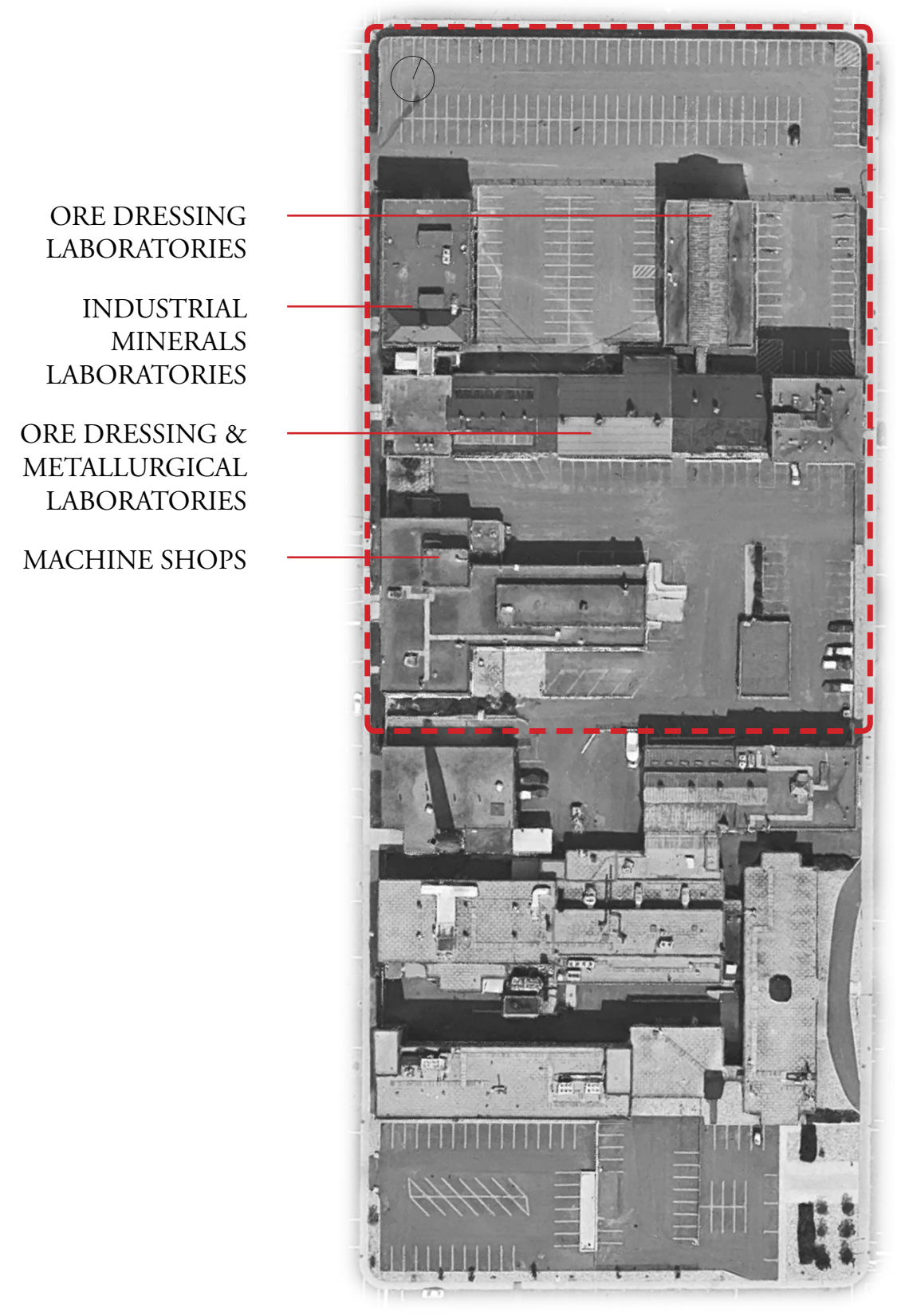

42. Site plan indicating extents of intervention area 
The various programs are organized into two over-arching types: global and local. The Rochester Street front is designated as the "global" façade and faces west toward bustling Little Italy. The once bleak and impenetrable street front is activated with programs serving the city as a whole: the library, business incubator, archive, supply shop, and gallery. The strategic site organisation augments the complex's connection to the city by providing programs which will draw citizens to the site from Preston Street (figure 44).

The Booth Street front is designated as the "local" façade and faces the residential area known as the Glebe Annex. This area houses the community centre, administrative buildings, and gallery. 

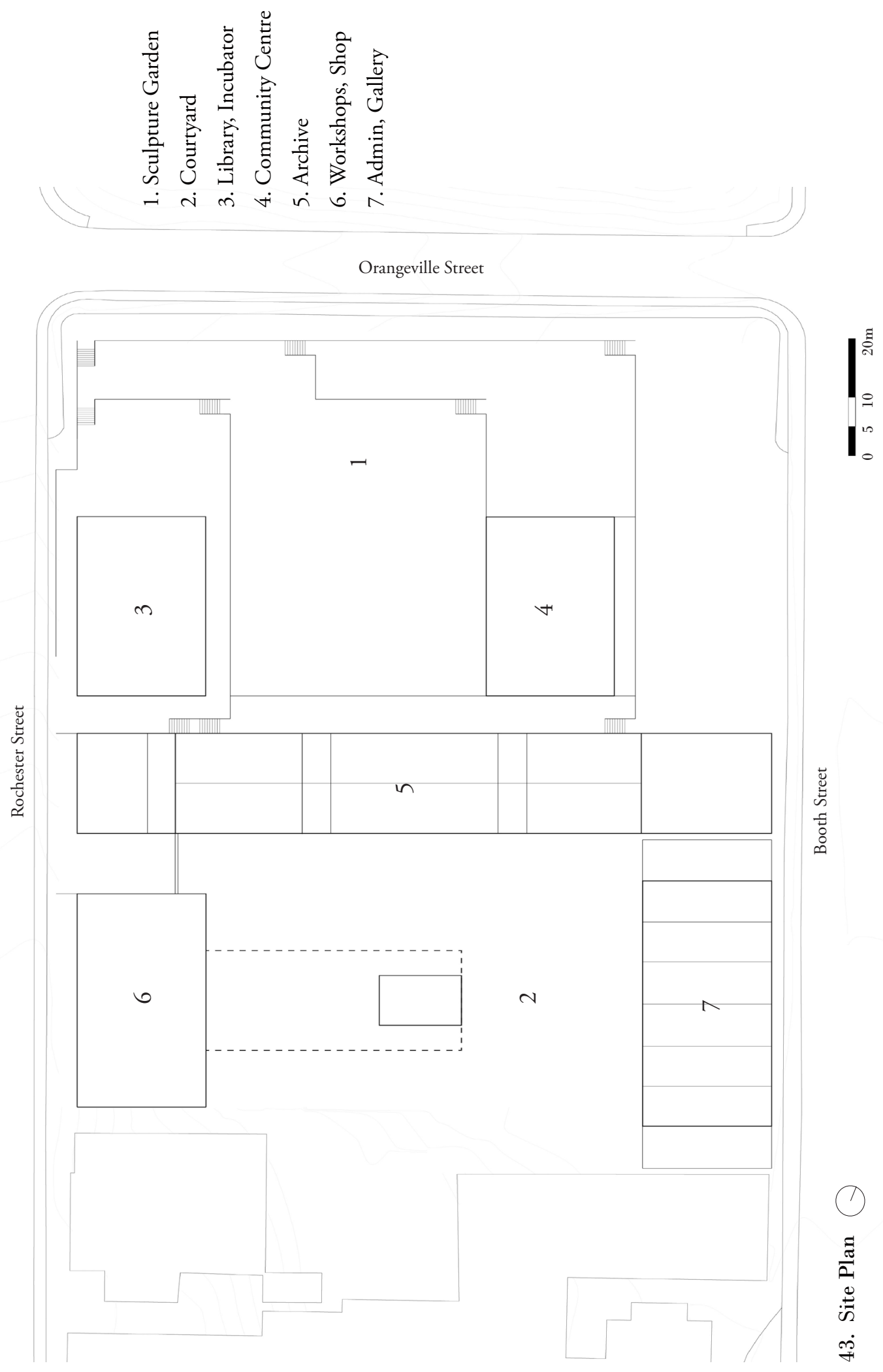
1. Sculpture Garden $\quad$ 6. Art Shop

2. Library 7. Gallery

3. Cafe

4. Incubator

8. Workshop

5. Archive

9. Studio

10. Services
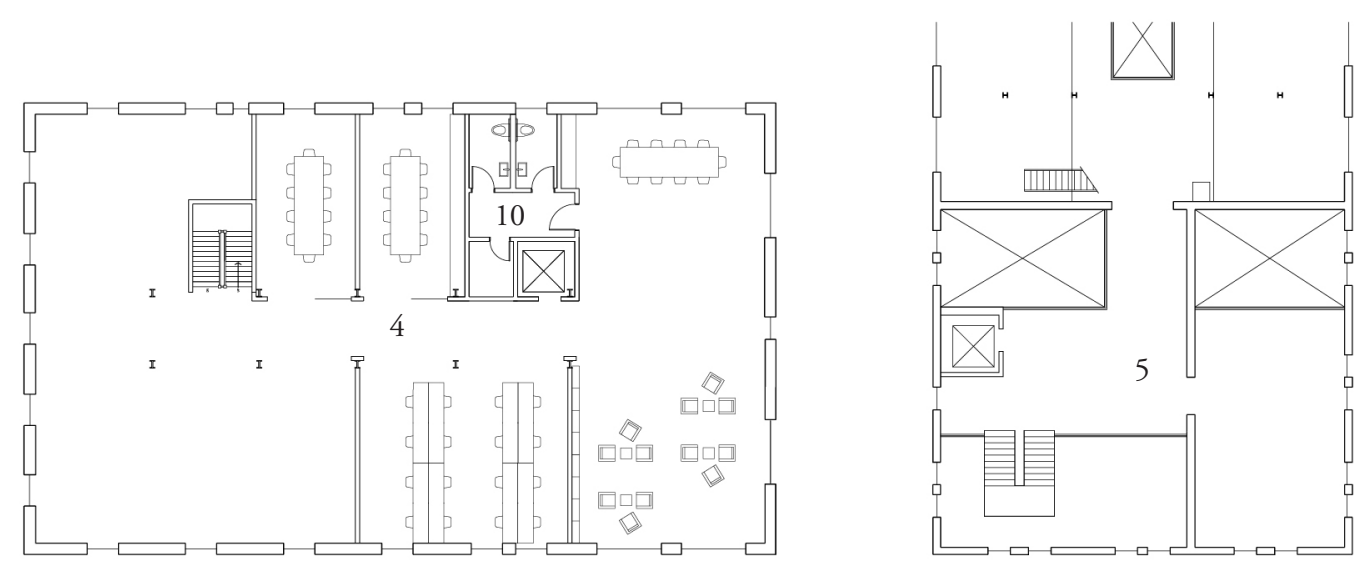

Third Floor Plan 1:100

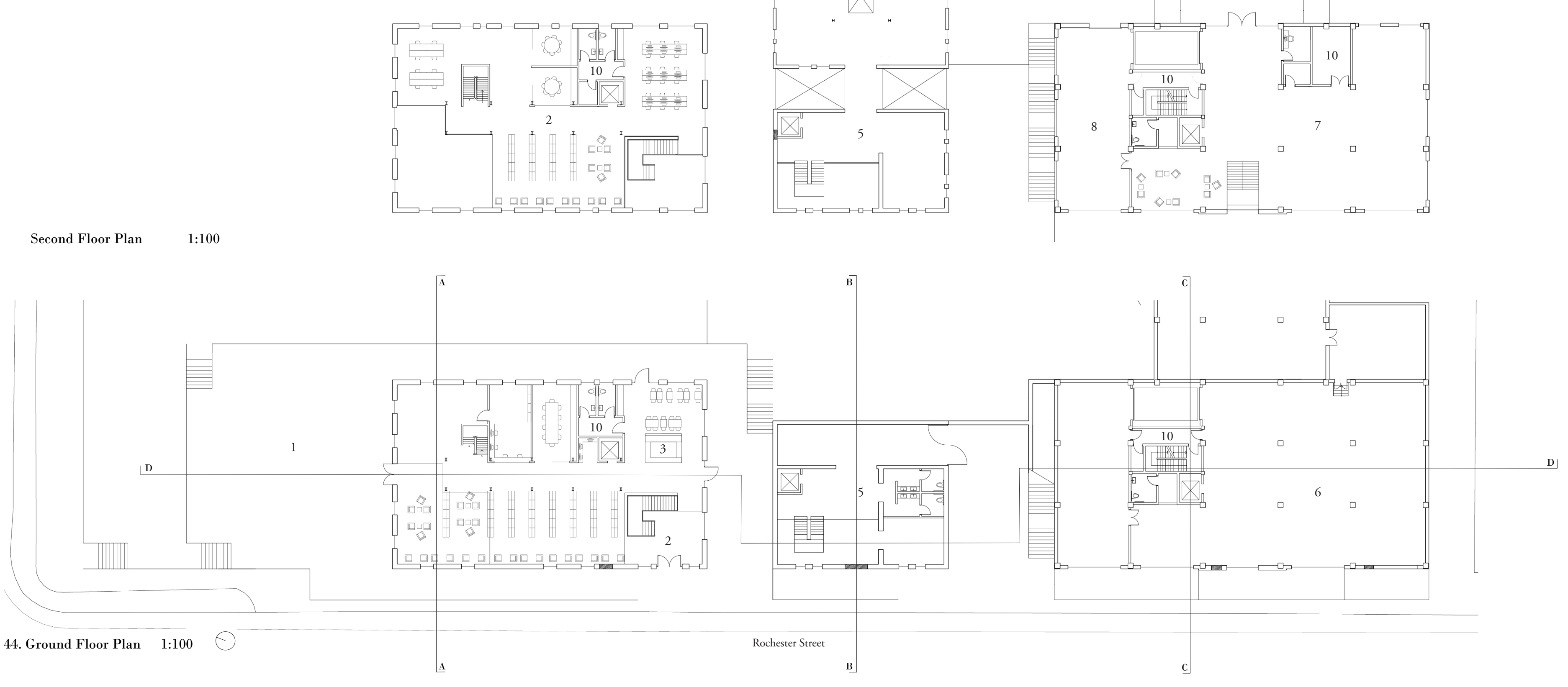

Second Floor Plan

1:100

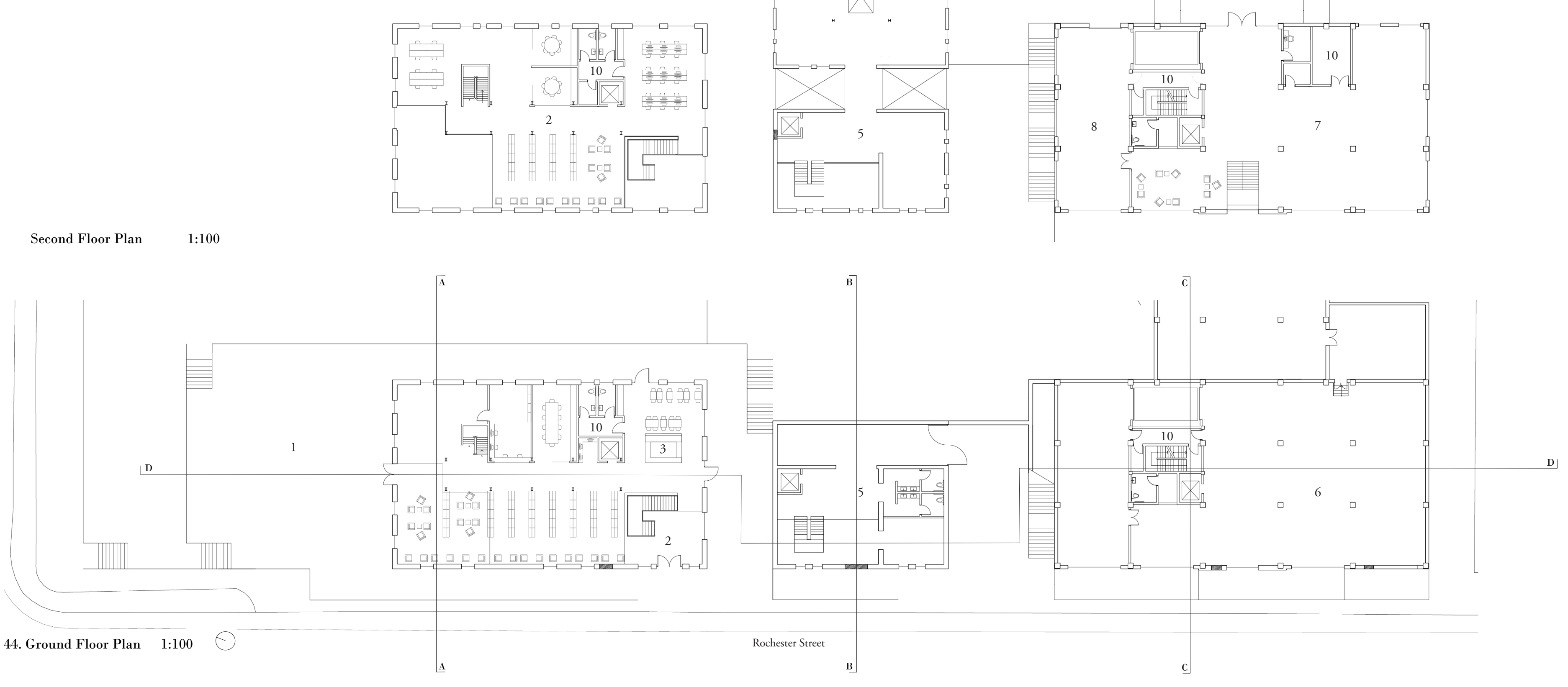

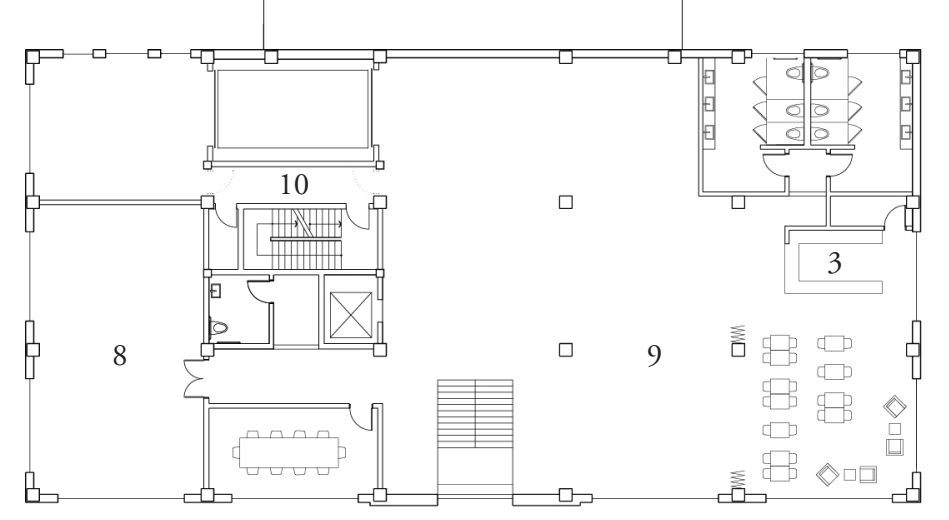

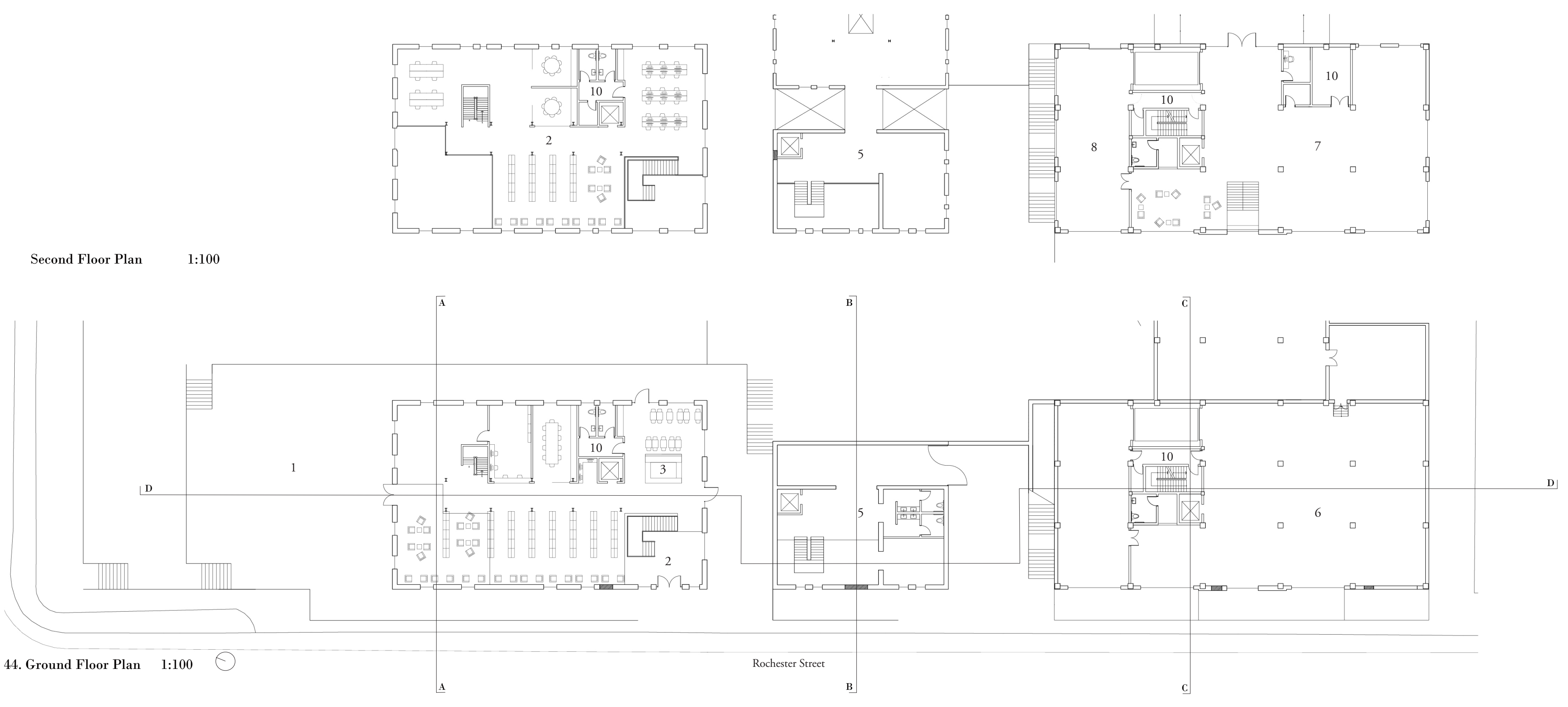


Currently, the buildings, retaining walls, and fences along Rochester Street create an impenetrable street front (figure 45). To enable circulation through the site, portions of the retaining walls are pushed back from the sidewalk in order to create small pockets between buildings where exterior stairs lead up to the main courtyard. Chainlink fences are removed to enable the flow of East-West circulation and increase the site's porosity.

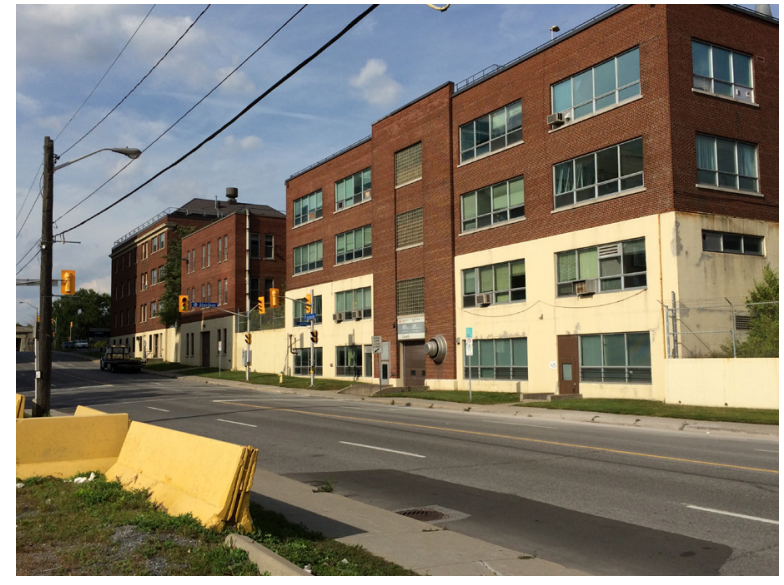

45. Rochester Street, current condition 


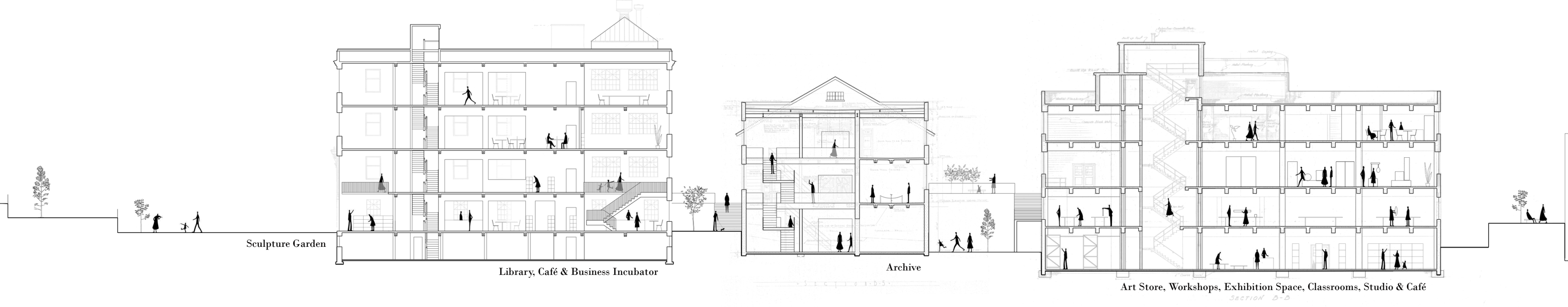


The Ore Dressing \& Metallurgical Laboratories runs the full width of the site from Booth Street to Rochester Street, completely bisecting the complex and isolating the Industrial Minerals Laboratories and the Ore Dressing Laboratories (figure 43). Cutting several large openings into the façade, along the seams where the buildings were joined, creates visual connections and allows movement through the buildings along the North-South axis.

The site is located along a natural ridge. There is a three-metre change in grade, rising from west to east. The landscape design works with the topography by transforming the sloping parking lot along Orangeville Street into a stepped plaza (visible from the Queensway). This new public space holds a sculpture garden showing decommissioned machinery and raw materials removed during deconstruction, thereby encouraging visitors to imagine possible future lives of industrial artefacts (figures 47-49). 


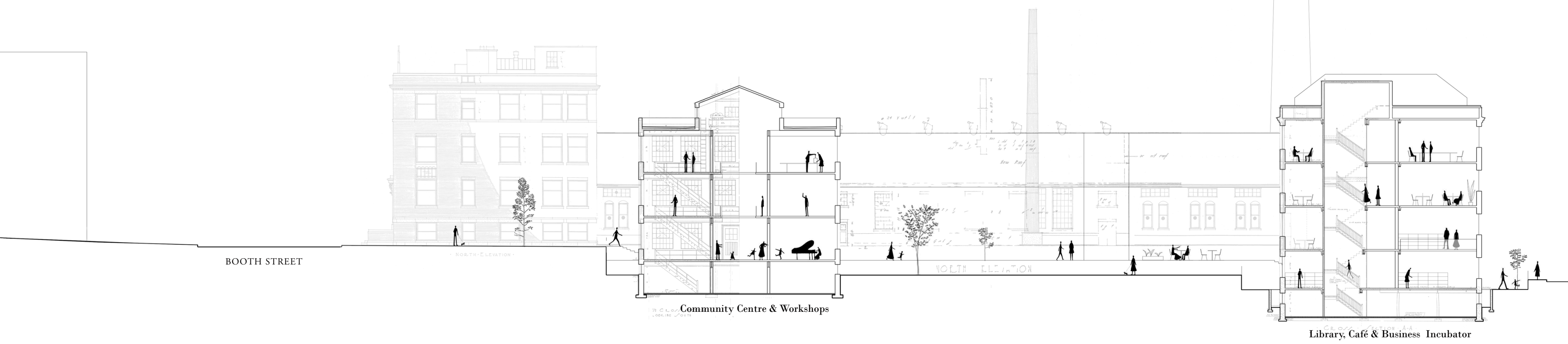

47. Section A-A 1:100 


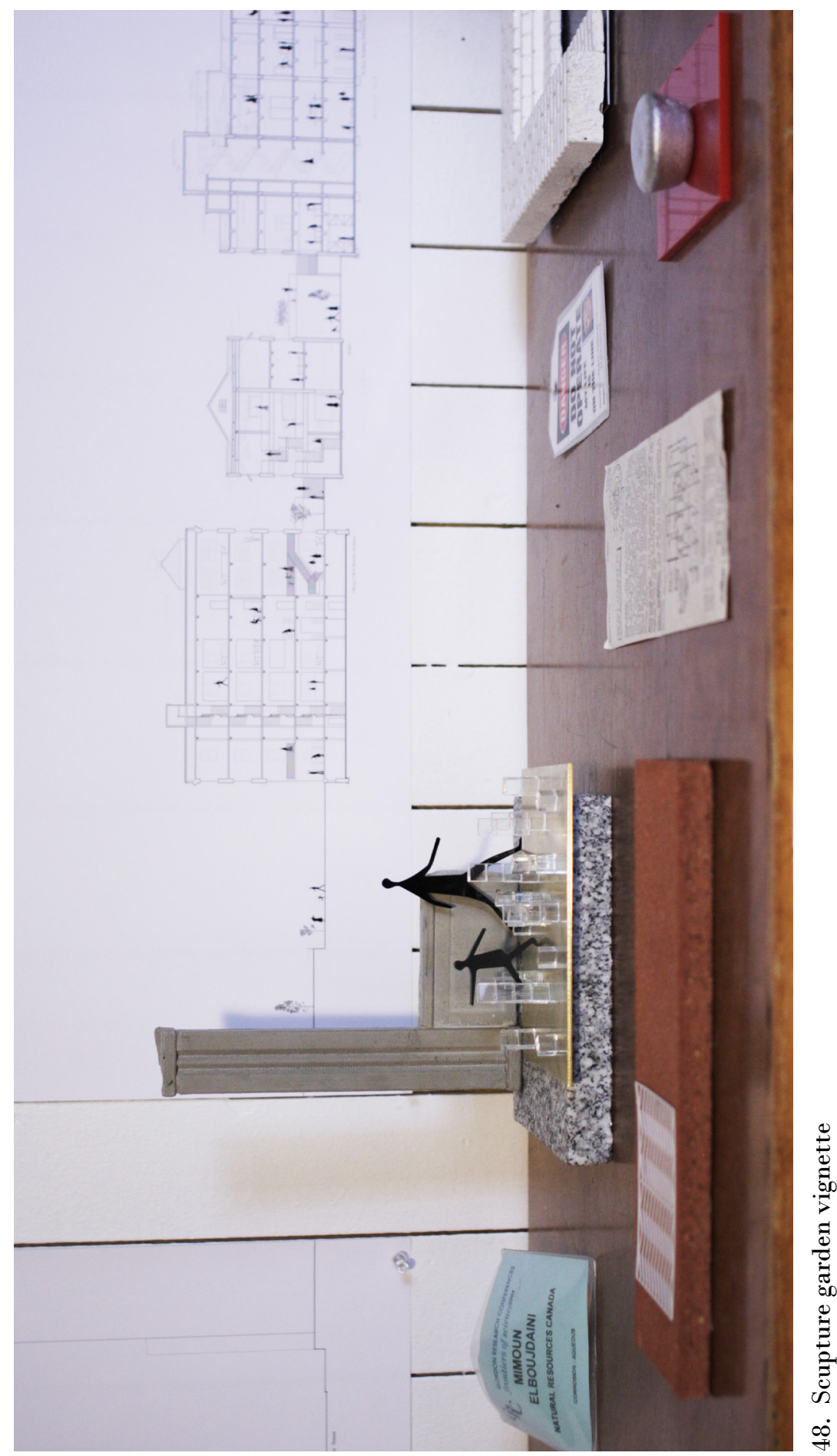




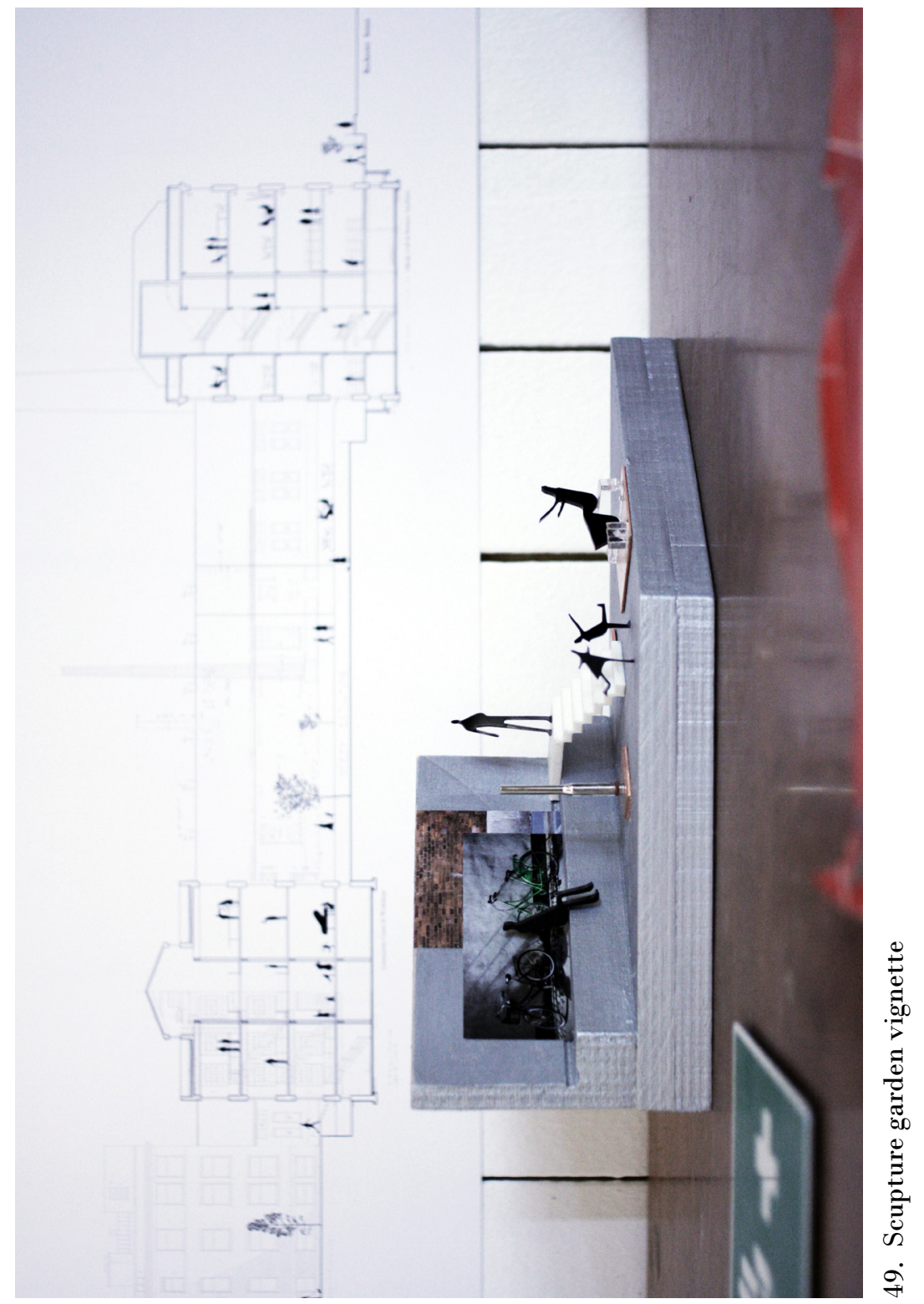


The addition of the new building on Booth Street creates a second public space at the centre of the complex. The central courtyard is simply a clarification and refinement of what was already present: a central open space, loosely defined by irregular building facades on three sides and a chain link fence on the fourth. The new building encloses the open space, firmly defining the boundaries of the courtyard. Additionally, the proportions of the courtyard are ameliorated by removing a portion of the machine shops building. This thoughtful deconstruction purposefully reveals the formerly concealed crane well, leaving it standing in a sea of columns as the centerpiece of the courtyard.

The courtyard is accessed by new exterior stairs leading up from Rochester Street. From Booth Street, visitors enter the courtyard by passing between historic buildings and the new building, beneath a reflective roof. This portal acts as a formal threshold and creates sense of arrival upon entering the site. 


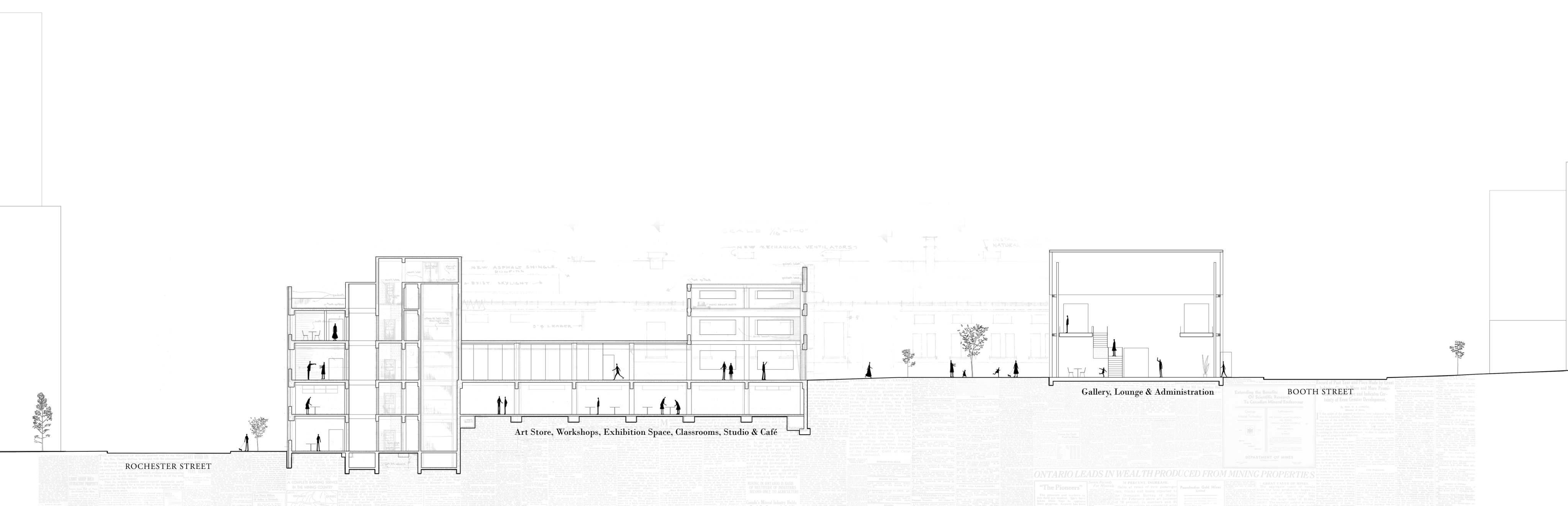


The Industrial Minerals Laboratories and the Ore Dressing \& Metallurgical Laboratories both have stairs leading up to the principal entrance, thus making them inaccessible to people with physical disabilities. These buildings will be made accessible by lowering the entrances to grade.

The grade will also be lowered. Daylight enters the lower levels by new light wells running the length of the buildings.

\section{Tectonics}

Predominant themes include complexity, contradiction, tension, and juxtaposition. These themes are embodied in acts of filling in, nesting, mirroring, overlapping, and deconstructing; architecture to inspire making.

\section{Forensic Architecture}

The architecture highlights the importance of respecting past alterations and reading the existing structures for design cues. The first rule of this sort of forensic architecture is to leave evidence intact. The significant 
modifications made over time are not undone. For example, rather than reinstating a sealed-up opening, a new opening with distinctly different character is created elsewhere.

When the design proposes significant alterations to the existing structure, the as-found condition is first documented and preserved through rerepresentation. At the same time, old buildings are considered "raw material" available for reuse.

The design intervention takes cues from the material evidence, or the "material memory". For example, the brick seams of the Ore Dressing and Metallurgical Laboratories reveal the boundaries of the original buildings. Rather than attempting to physically separate and isolate the individual buildings, the intervention carefully replaces portions of the brick walls with a transparent material, thereby indicating the boundaries. 

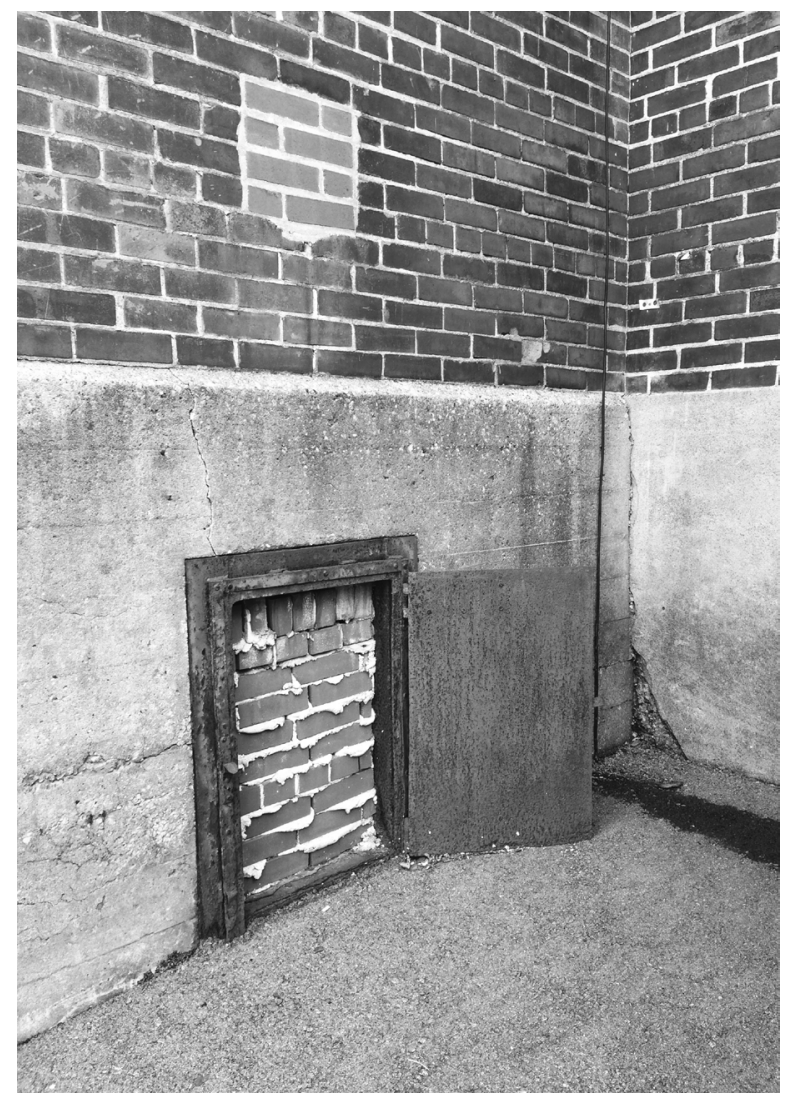

51. Evidence of alterations 


\section{Authenticity}

The architectural interventions uphold an allegiance to authenticity. It stands in opposition to the reproduction of lost architectural elements and the blending of contemporary and historic architecture. Although the new construction is distinctly different, the architecture shares a common language with the historic buildings. The existing buildings are described as modernist architecture with modest detailing in a classical style. Defining features include symmetrical façades, centrally organized floor plans, economic materials and very few decorative elements; typical of federal buildings constructed during the $1920 \mathrm{~s}$ and $1930 \mathrm{~s} .{ }^{39}$ The buildings' construction consists of a steel structural system, brick cladding and concrete floors. ${ }^{40}$

The design of the new building takes cues from the EMRC, referencing the fenestration patterns, symmetrical façades, and structural system. The slope of the roof is taken from the roof of the oldest existing building on the site, which was constructed in 1912 and is now part of 
the Ore Dressing and Metallurgical Laboratories. ${ }^{41}$

This zig-zagging pitched roof is a playful interpretation of the heritage roof structure and respects the existing industrial vernacular. Openings punched through thick masonry walls create a symmetrical façade and enhance the contrast between solid and void (figure 52).

The intervention juxtaposes the industrial with the palatial by putting together things which are not meant to be together. Introducing noble materials—such as copper, brass, and terrazzo-to industrial forms results in a familiar architecture with distinctly new character (figure 54). These materials appear sparingly in the original architecture and are all produced domestically. They have been selected for the intervention because of their significance in Canada's mining history. 


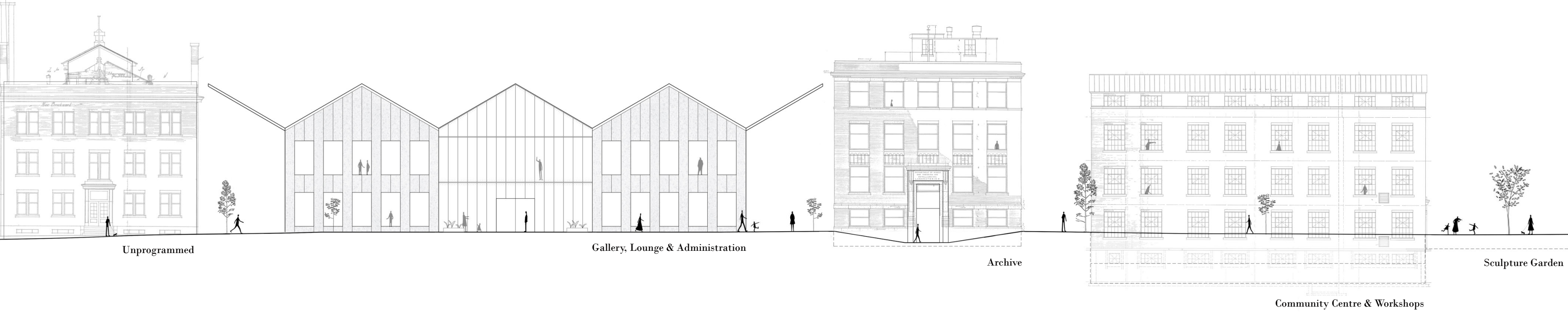


4. Lounge

5. Administration

6. Gallery
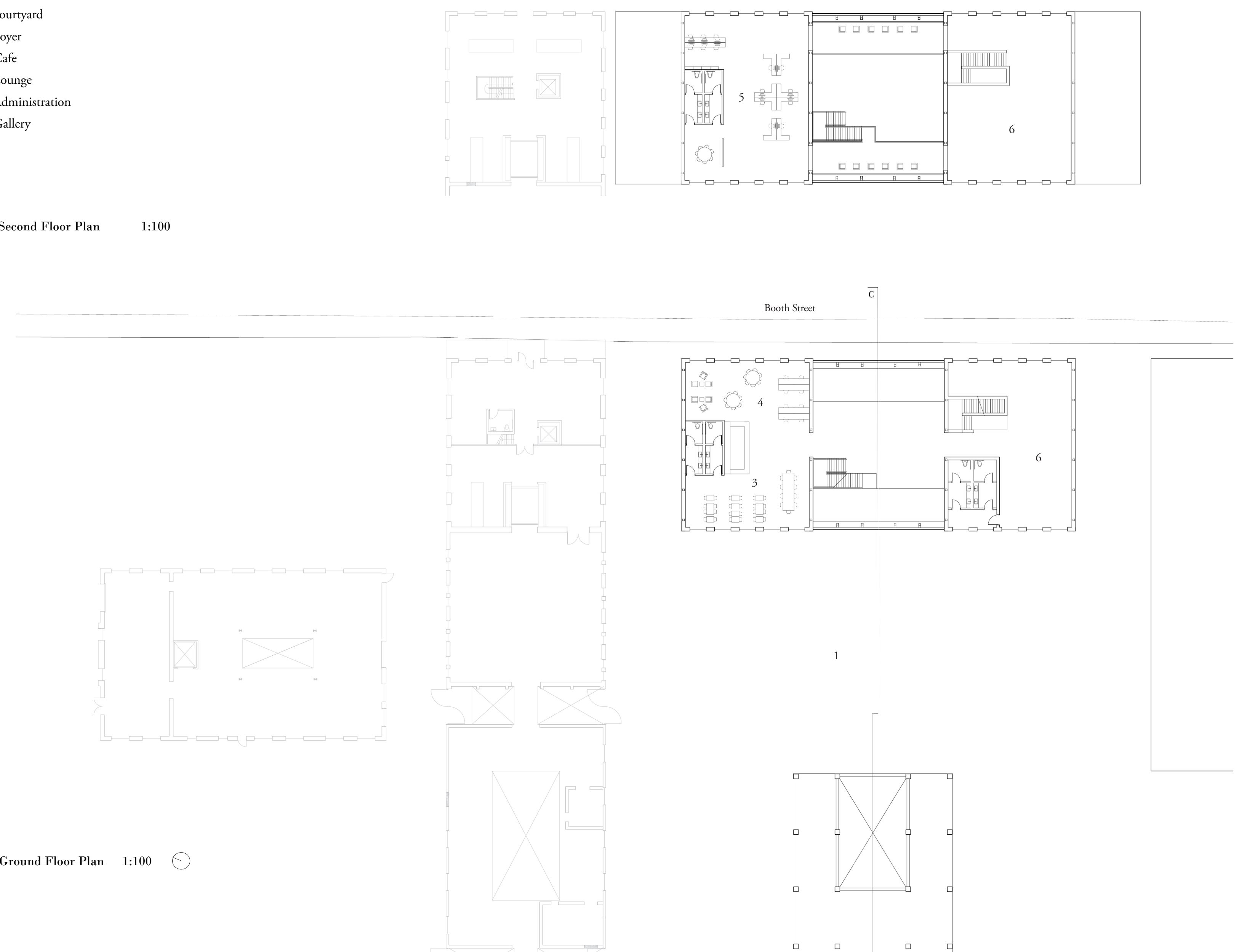


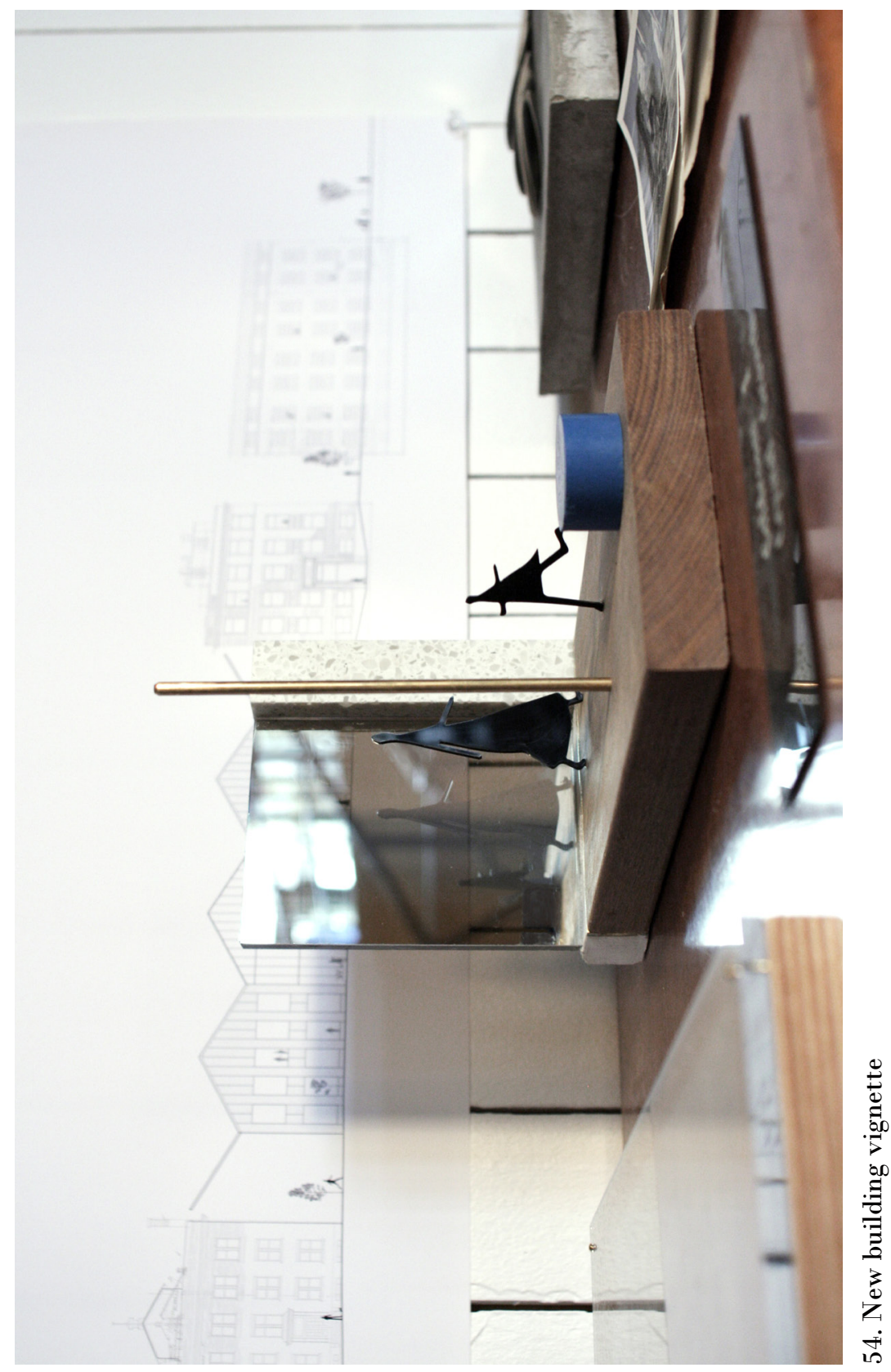




\section{The Archive}

The Ore Dressing \& Metallurgical Research Laboratories (552 Booth Street) houses the archive stretching the full width of the complex from Booth Street to Rochester Street.

Visitors enter on the lower level by passing through a new courtyard on Rochester Street, where a tunnel—dug into the previously unexcavated gap between foundationsleads to the reception area (figure 55).

To reveal the history of the conglomerate structure, the intervention separates the individual buildings visually and physically. At the seams, where the buildings were stitched together, expanses of glass break up the continuous brick façade. Behind the glass façade, the second-level floor plates are removed to create new double-height spaces with voids emphasizing the gaps in time between periods of construction (figure 56, 59).

A series of bridges pass through the voids, linking the archive's different rooms and creating a central 


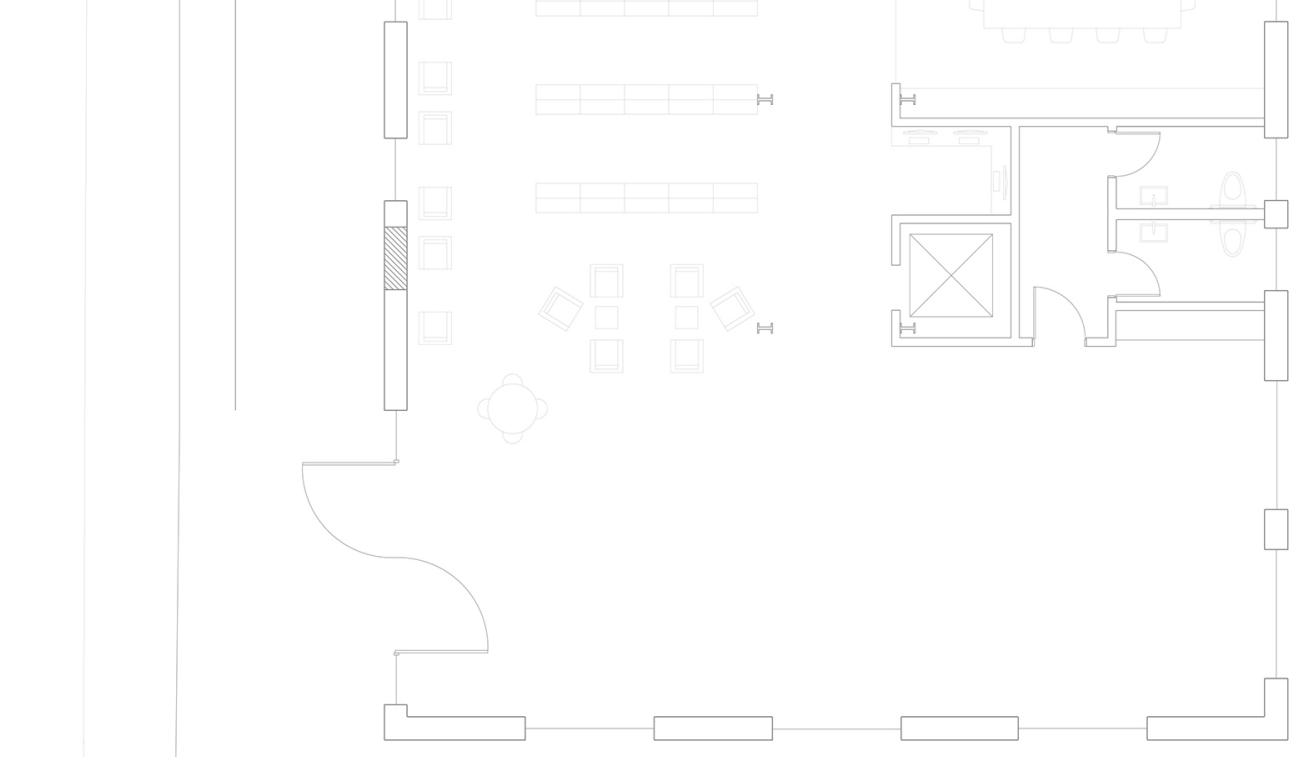

55. Archive, basement plan 


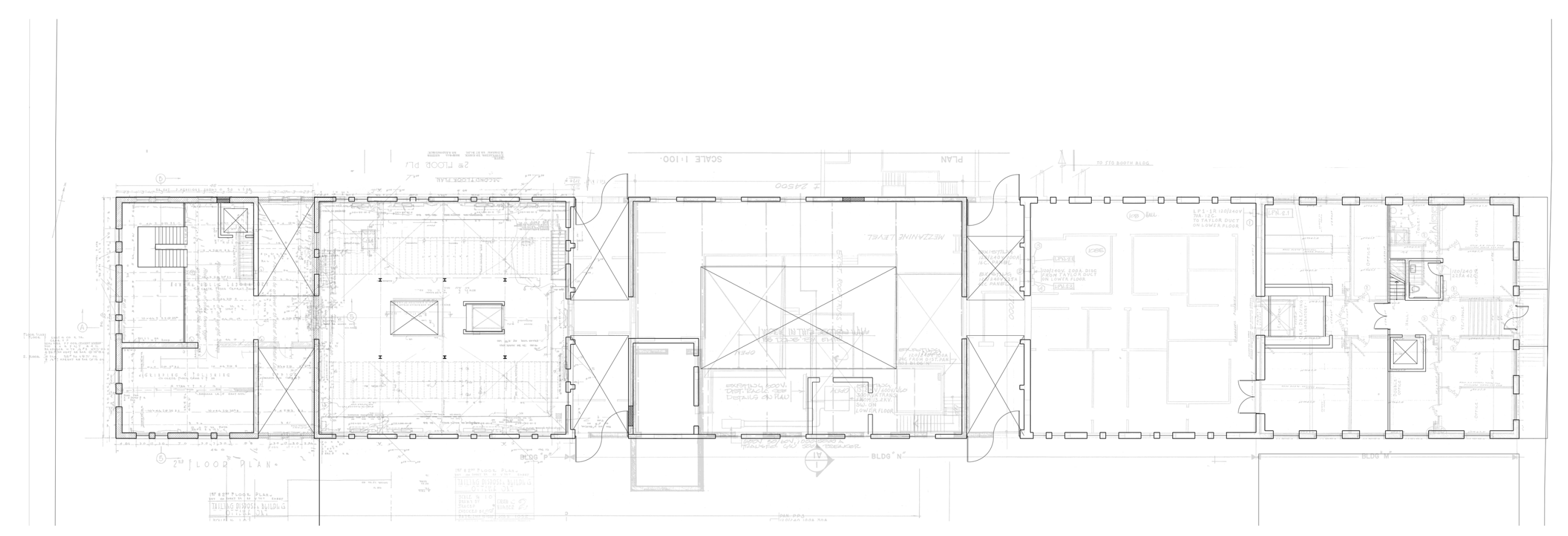

Second Floor Plan $\quad$ 1:100

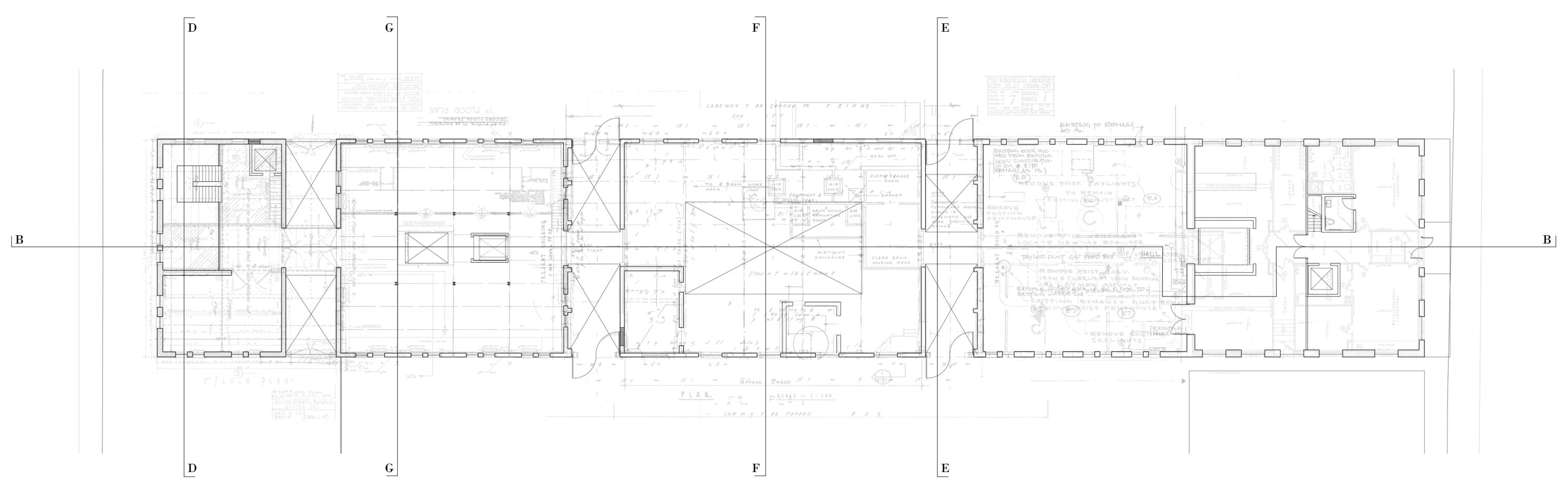

56. Archive Ground Floor Plan $\quad$ 1:100 


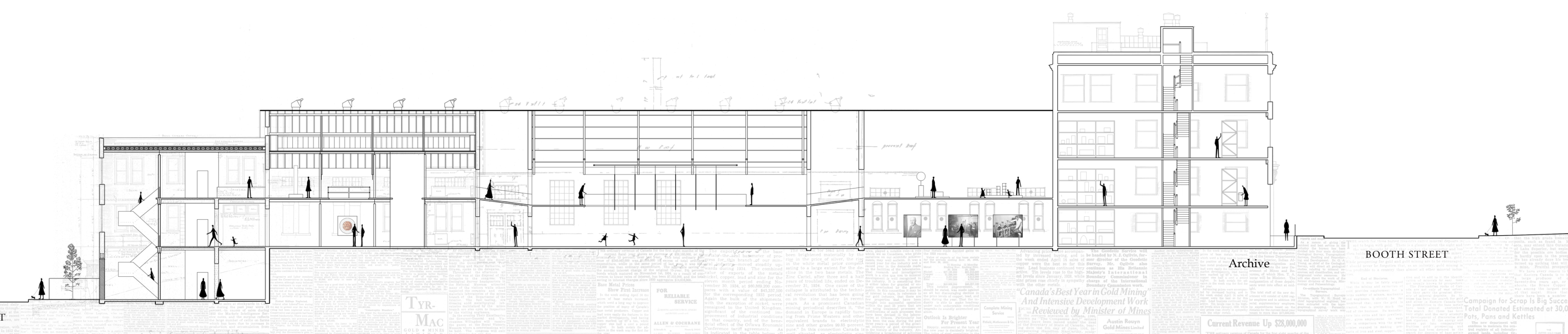


passageway. The new threshold condition encourages visitors to pause and reflect on the subtle changes in structure as they progress down the central passageway. These voids allow visitors to inhabit the section, bringing to life what typically exists only as a two-dimensional drawing (figure 59).

The openings visitors pass through while walking the central passageway have been enlarged to accommodate the new program. To create a clear distinction between the existing building and contemporary modifications, the new openings in the brick walls are finished with cast in place concrete (figure 58).

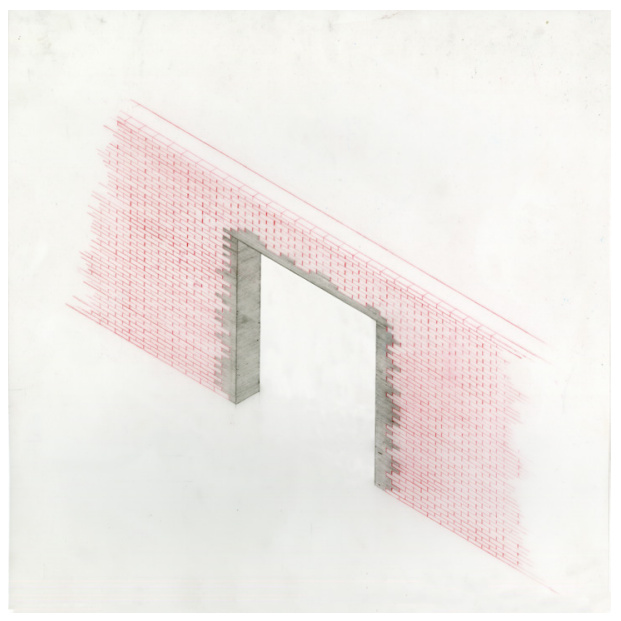

58. Material Strategy 
Crossing the bridge, visitors can glimpse a series of translucent panels hanging from the existing roof structure in the adjacent room. The images on the panels depict site transformations through time. Each of the panels is dated to provide visitors with a better understanding of the site's long and complex history. The panels hang above an opening in the floor and can be viewed from the lower level. The new floor is offset from the exterior brick walls, leaving a reveal to emphasize the difference between the old structure and the new (figure $60)$.

Delicate artefacts and documents recovered from the site are displayed in protective display cases, while material studies and contemporary works are displayed informally (figure 61). The aim is, again, to contrast the old and new. These are not sacred objects; this is an archive of informality which permits visitors to bring their own memories to the site and to interpret things freely (figures 62-67). 

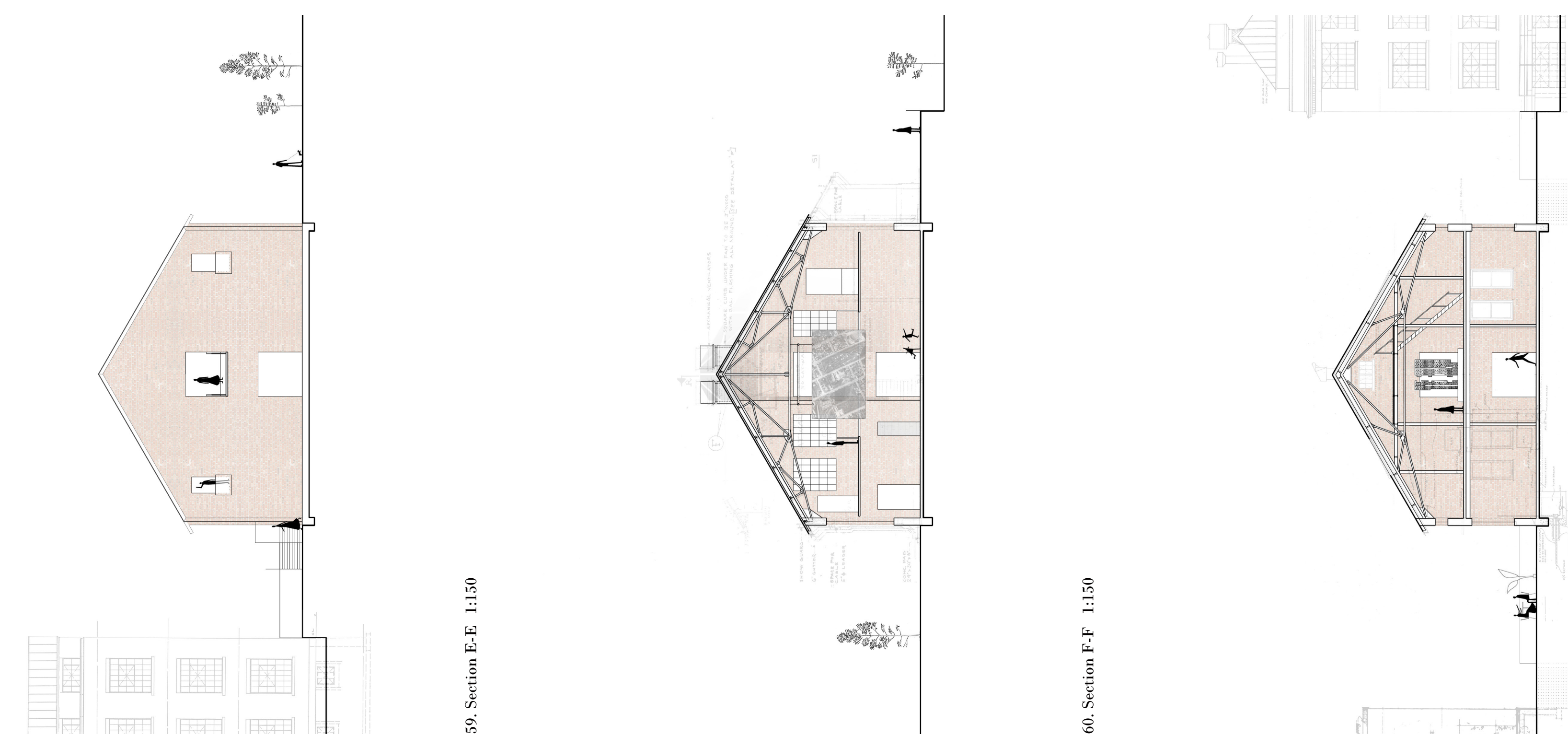


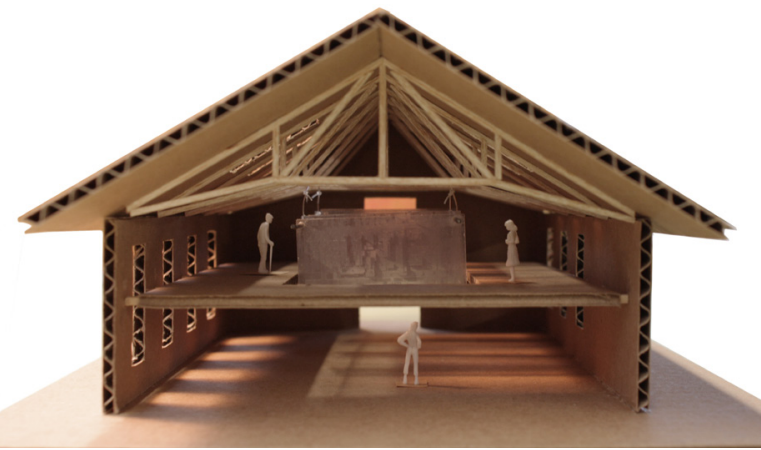

62. Site History Installation

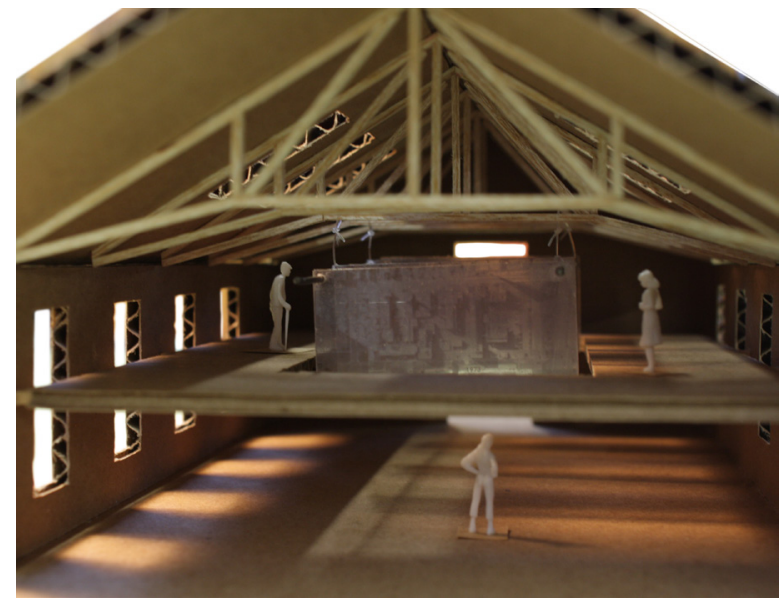

63. Site History Installation 


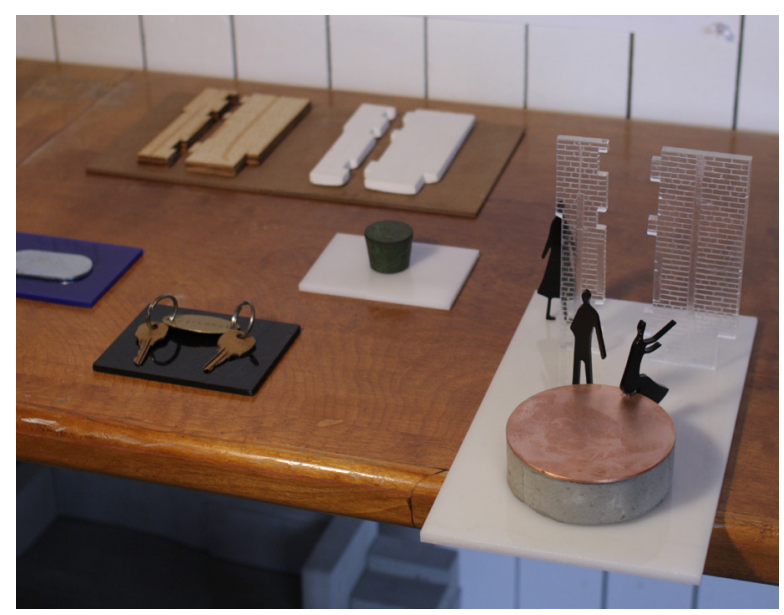

64. The Archive

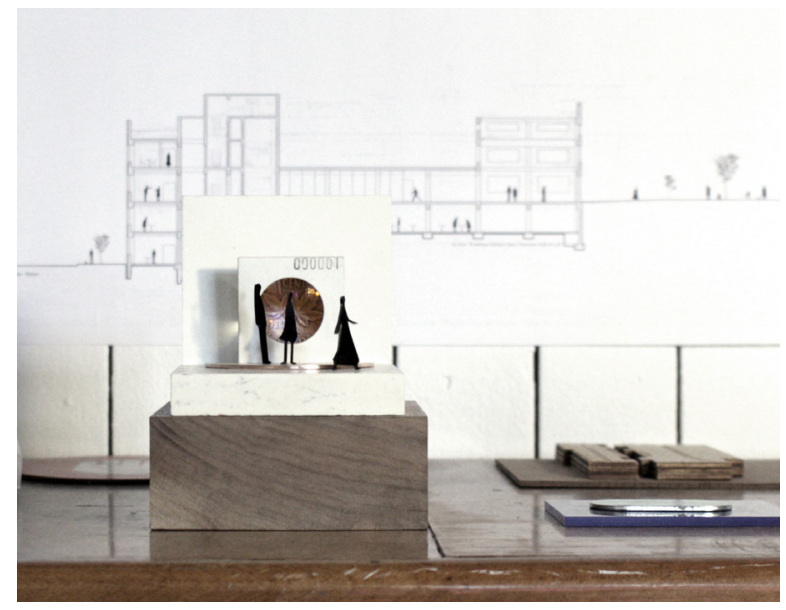

65. The Archive 


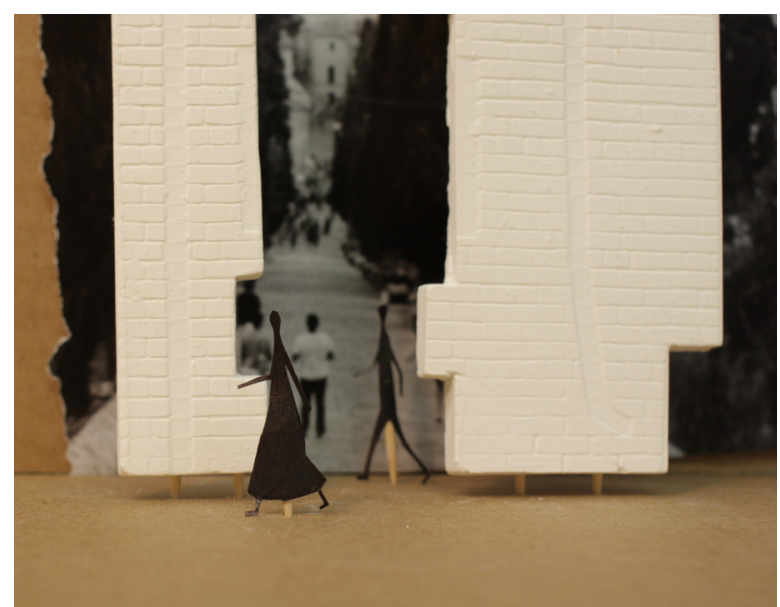

66. The Archive

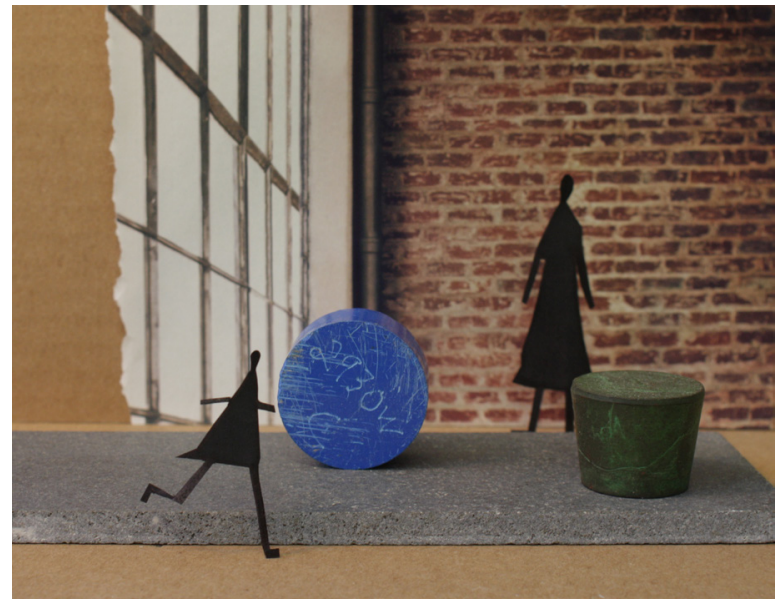

67. The Archive 


\section{Conclusion}

At the outset of this project, prior to the federal election in October 2015, Canada's cultural climate was one where science had been devalued by government and craft had been devalued by a society in favor of mass-produced $\operatorname{goods}$.

Returning the site to its once productive state will counter-balance the accelerating gentrification of the area by implanting a catalyst for small-scale grassroots production. Rather than adding to Ottawa's list of commercial mixed-use developments, the site can become a hub for creativity and making. The project will not only contribute to the local economy on a small scale-benefiting individuals, not developers-but also benefit community members on a more personal level by allowing them to get back in touch with their spirit for making. 
The tectonics of the new architecture honour the industrial vernacular, inornate symmetrical facades, punched openings through thick masonry walls and reinterpreting the shed roof while thoughtfully designed thresholds where old meets new honour the spirit of making which imbues the complex.

The introduction of noble materials—such as copper, brass, and terrazzo-to industrial forms honours the significant role that mining played in Canada's economic development and materialises the link to Canada's national identity.

This project honours the traditions of science and craft which were once an integral part of our Nation's identity. Exploring materiality, craft, and permanence, the thoughtful appropriation and reprogramming of the site grants the complex continuity of life and continuity of meaning, creating a place where people can bring their memories to the site and continue to discover memories. 
Although the research is focused on the Energy, Mines and Resources Complex and its significance as a narrative of Canada's material and industrial history, it provides new alternatives for reimagining the futures of urban industrial complexes and governmental sites.

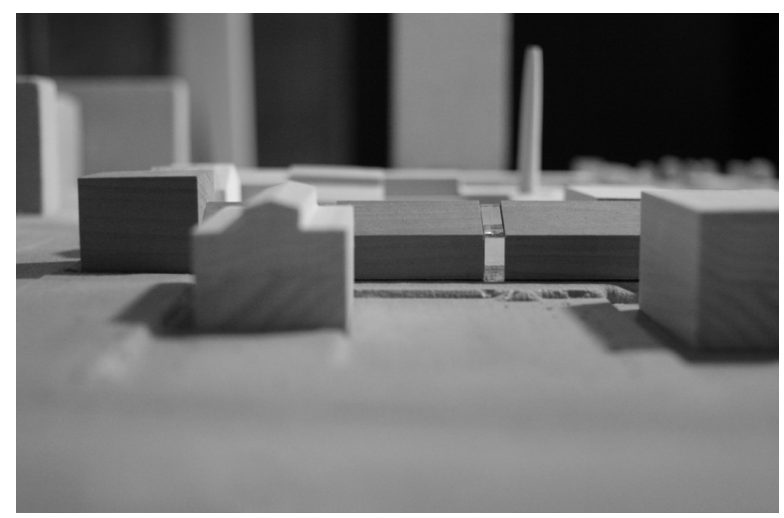

68. Concrete Site Model 


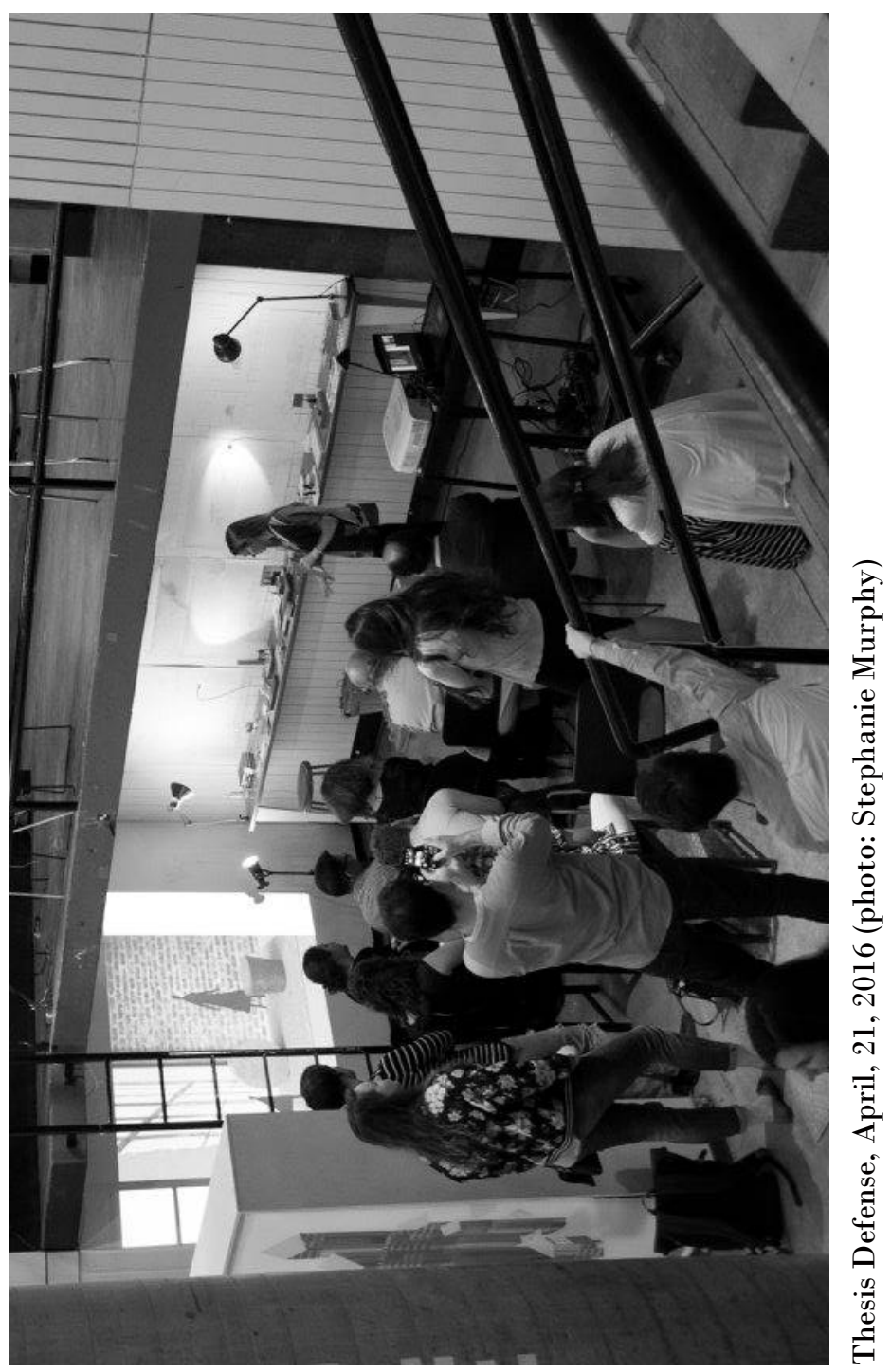




\section{References}

1. Ricketts, Shannon, "Four Structures on the EMR Complex, Booth Street, Ottawa," Heritage Buildings Review Office: 86-61 (1982- ), 29

2. Bellamy, Rhoda, "The Architecture of Government," in Construire Une Capitale - Ottawa - Making a Capital, eds. Jeff Keshen and Nicole StOnge (Ottawa: University of Ottawa Press, 2001), 434

3. Ibid., 441

4. Ricketts, "Four Structures on the EMR Complex," 25

5. Ibid., 37

6. "Ontario Gets $\$ 10,000,000$ in New Works," Ottawa Journal (Ottawa, ON), June 20, 1934

7. Ricketts, Shannon, "W.E. Noffke: an Ottawa Architect," (master's thesis, Carleton University, 1989), 32

8. Burd, Dylan, "Somerset House Facelift Delay Wears Thin," Centretown News (Ottawa, ON), Oct. 22, 2015, http://www.centretownnews. ca/front-page-mainmenu-127/5478-somerset-house-facelift-delay-wearsthin.html

9. Willing, Jon, "City Approves Redevelopment for Decrepit Somerset House," Ottawa Sun (Ottawa, ON), Nov. 13, 2013, http://www. ottawasun.com/2013/11/13/city-approves-redevelopment-for-decrepitsomerset-house

10. Canada Lands Company, "Booth Street Northwest and Central Quadrants, Ottawa, Ontario, Acquisition Business Plan," October 2013

11. Gatehouse, Jonathon, "When Science Goes Silent," Maclean's, May 3, 2013, http://www.macleans.ca/news/canada/when-science-goessilent/

12. McGregor, Janyce, "Federal Budget 2016: Liberals Push Deficit To Spend Big On Families, Cities," CBC News, Mar. 22, 2016, http://www. cbc.ca/news/politics/federal-budget-2016-main-1.3501802 
13. Trudeau, Justin, "Minister of Science Mandate Letter," http:// pm.gc.ca/eng/minister-science-mandate-letter

14. Ouroussoff, Nicolai, "An Architect's Fear That Preservation Distorts," The New York Times (New York City), May 24, 2011: C1

15 . Roth, Deborah C., "Wish You Were Here: A Cross-Cultural Analysis Of Architectural Preservation, Reconstruction, And The Contemporary Built Environment" 30 Syracuse Journal of Int'l Law \& Commerce 395. (2003), 419

16 . Federal Heritage Buildings Review Office. Heritage Character Statement: Ore Dressing Laboratory 86-061 (1997)

17. Solà-Morales Rubio, Ignasi, Differences: Topographies of Contemporary Architecture, trans. by G. Thompson (Cambridge, MA: MIT Press, 1997), 6

18 . Ibid., 16

19 . Ricketts, Shannon, "Energy, Mines and Resources Complex: Ore Dressing Laboratory," Directory of Federal Heritage Designations, Mar. 13, 2012, http://www.pc.gc.ca/apps/dfhd/page_fhbro_eng.aspx?id=2851

20 . Latour, Bruno, Yaneva, Albena. “Give Me a Gun and I Will Make All Buildings Move': An Ant's View of Architecture," in Explorations in Architecture: Teaching, Design, Research, ed. Reto Geiser, (Basel: Birkhäuser, 2008), 80-89

21 . Ibid.

22 . Ibid., 49

23 . National Gallery of Canada, "Betty Goodwin," https://www. gallery.ca/en/see/collections/artist.php?iartistid=2098

24. Morin, France; Kwinter, Sanford; Goodwin, Betty, Betty Goodwin: Steel Notes, (Ottawa: National Gallery of Canada, 1989), 17

25 . Whiteread, Rachel, et al. Rachel Whiteread (London; Edinburgh: Scottish National Gallery of Modern Art, 2001), 9

26 . Ibid., 11

27 . Ibid., 10 
28 . Kropotkin, Peter, Fields, Factories and Workshops of Tomorrow, (London: Allen \& Unwin, 1974), 171

29 . Ricketts, "Four Structures on the EMR Complex," 36

30 . Kropotkin, Fields, Factories and Workshops of Tomorrow, 178

31 . Berkowitz, Roger, "Labor of Love," Hannah Arendt Centre, Bard College, Jan 25, 2013, http://www.hannaharendtcenter.org/?p=9141

32 . Crawford, Matthew B., Shop Class as Soulcraft: An Inquiry into the Value of Work, (New York: Penguin Press, 2009), 10

33. Kropotkin, Fields, Factories and Workshops of Tomorrow, 180

34. Crawford, Shop Class as Soulcraft, 15

35 . Ibid., 18

36 . Wright, Janet, Crown Assets: The Architecture of the Department of Public Works, 1867-1967, (Buffalo; Toronto: U of Toronto, 1997), 170

37. Keshen, Jeff, "World War Two and the Making of Modern Ottawa," in Construire Une Capitale - Ottawa - Making a Capital, eds. Jeff Keshen and Nicole St-Onge (Ottawa: University of Ottawa Press, 2001), 384

38. Arendt, Hannah, The Human Condition, (Chicago: The University of Chicago Press, 1958), 95

39. Keshen, "World War Two and the Making of Modern Ottawa," 384

40. Ricketts, "Four Structures on the EMR Complex," 50

41. Ibid., 34 